\title{
Irrelevance of Governance Structure
}

\author{
Zohar Goshen* \\ Columbia and ECGI \\ Doron Levit ${ }^{\dagger}$ \\ January 31, 2019 \\ Preliminary, comments are welcomed
}

Wharton and ECGI

\begin{abstract}
We develop a model under which the allocation of control rights between shareholders and managers is irrelevant to firm value. In our model, multiple firms buy resources for their business activities in a competitive market. Shareholders deduct from decisions made by managers, who differ in their integrity, whether a manager should be retained or fired. The allocation of control rights allowing a shareholder to fire a manager can either be easy ("strong governance") or impossible ("weak governance").

The model shows that independent governance choices of individual firms are interrelated through the feedback from resources markets. In a competitive equilibrium, which is socially efficient, the universe of firms splits between strong and weak governance firms, with all of them having the same value. No firm can improve its value by changing from weak to strong governance or vice versa. The governance structure is irrelevant.

The irrelevance result has important implications for the study of corporate governance. First, since shareholders with market power violate the irrelevance conditions, the model provides insights into the consequences of common ownership. It shows that, by pushing more public firms toward strong governance, institutional investors with common ownership create a monopsony power, with negative consequences to the labor market, the inputs market, the investment level in the economy, and the number of firms traded on public markets. Second, the model illuminates the need for empirical studies to specify the conditions under which strong governance is assumed to consistently be better than weak governance.
\end{abstract}

JEL: D20, D21, D23, D24, D61, D74, D83, D86, G23, G30, G32, G34, K22, L12, L40

Keywords: Corporate Governance, Common Ownerhip, Market Power, Shareholder Rights, Control Rights, Agency Costs.

*Email: zgoshen@law.columbia.edu.

†Email: dlevit@wharton.upenn.edu. 


\section{Introduction}

Starting with Jensen and Meckling's seminal 1976 article, agency costs have been the central element in the theory of the firm and the study of corporate governance. Although Jensen and Meckling's model focused only on the capital structure of the firm (the agent held all voting rights), it was, as well, applied to the firm's governance structure. Indeed, the central theme in the theory of corporate governance is that empowering shareholders-i.e., allocating more control rights to shareholders - will allow shareholders to hold disloyal managers accountable, and therefore, reduce agency costs (Bebchuk 2005). The empirical prediction that follows is that a weak governance structure -i.e., allocation of more control rights to managers - will be associated with weak firm value and performance due to a high level of agency costs (Gompers, Ishii and Metrick, 2003).

However, a review of empirical studies reveals that every aspect of corporate governance that was studied in the last forty years yielded conflicting empirical findings (Goshen and Squire 2017), for instance: the level of cash flow rights held by management; ${ }^{1}$ dual-class shares; ${ }^{2}$ antitakeover defenses,${ }^{3}$ such as poison pills, ${ }^{4}$ staggered boards, ${ }^{5}$ and protective state legislations; ${ }^{6}$ hedge-fund activism; $;^{7}$ and the strength of corporate governance as measured by several indices. ${ }^{8}$

Interestingly, despite the inconclusive empirical evidence, institutional investors with common ownership are consistently pushing toward strong governance structure for publicly traded firms (Smith 1996; Carleton, Nelson and Weisbach 1998; McCahery, Sautner and Starks 2016), via, for instance, destaggering boards (Bebchuk, Hirst and Rhee 2013), limiting the use of poison pills (Subramanian 2014), excluding dual-class firms from the indices (Friedman 2017),

\footnotetext{
${ }^{1}$ Compare Demsetz and Lehn (1985), Himmelberg, Hubbard and Palia (1999), and Demsetz and Villalonga (2001) with Morck, Shleifer and Vishny, (1988), McConnell and Servaes (1990), and Holderness, Kroszner and Sheehan (1999).

${ }^{2}$ Compare Smart, Thirumalai and Zutter (2008), Masulis,Wang and Xie (2009), Gompers, Ishii and Metrick (2010) with Partch (1987), Lehn, Netter and Poulsen (1990), Adams and Santos (2006), and Adams and Ferreira (2008).

${ }^{3}$ Straska and Waller (2014).

${ }^{4}$ Compare Ryngaert (1988) with Comment and Schwert (1995).

${ }^{5}$ Compare Bebchuk and Cohen (2005) with Bates, Becher and Lemmon (2008).

${ }^{6}$ Catan and Kahan (2016).

${ }^{7}$ Compare Brav et al. (2008) with deHaan, Larcker, and McClure (2018).

${ }^{8}$ Compare Gompers, Ishii and Metrick (2003) with Bebchuk, Cohen and Ferrell (2009) and Cremers, Masconale and Sepe (2016).
} 
demanding mandatory sunsets for dual-class firms, ${ }^{9}$ and supporting hedge funds governance initiatives (Brav et al. 2008).

What explain the conflicting empirical findings in the studies of corporate governance? And why, given the inconclusive empirical findings, institutional investors with common ownership are consistently pushing toward strong governance structures in public firms?

To answer these questions, we develop a model in which, a priori, corporate governance can either increase or decrease firm value. Our main result shows that in a competitive equilibrium, corporate governance is irrelevant to firm value. Importantly, we identify the conditions under which corporate governance is relevant, which enables us to inform the design of empirical studies and explain institutional investors' governance strategy and the consequences of common ownership.

Our model features multiple firms which run by managers and owned by shareholders. Managers, who differ in their integrity, can either preserve firm value by maintaining the status quo, or change firm value by investing. Investment requires resources (e.g., human capital, raw materials, intellectual property, corporate assets), which firms buy for their business activities in a competitive market. By investing, loyal managers create firm value, but disloyal managers consume private benefits and destroy firm value. The variation in managers' integrity, which is their own private information, captures the central theme of corporate governance theory that control rights are necessary to reduce agency costs - i.e., agent conflict. Shareholders, who are not fully informed, deduct from decisions made by managers whether a manager is disloyal and should be fired. Since managers have career concerns, the fear of being fired can discipline disloyal managers but also distort decisions made by those who are loyal. The allocation of control rights allowing a shareholder to fire a manager can either be easy ("strong governance"), such as in dispersed-ownership firms without staggered boards and poison pills, or impossible ("weak governance"), such as in dual-class firms with public shareholders owning non-voting shares. These control rights are allocated at the outset in each firm by its own shareholders, ${ }^{10}$ to maximize the expected value of the firm.

While shareholders do not control the investment policy of their firm, they can affect it indirectly through the firm's governance structure. In equilibrium, strong governance and the

\footnotetext{
${ }^{9}$ NYSE petition - Council of Institutional Investors, October 24, 2018.

${ }^{10}$ In our baseline model there is no common ownership; each firm is owned by a different set of shareholders.
} 
threat of being fired by shareholders, deters all types of managers from undertaking investment and buying resources; weak governance does the opposite. Intuitively, strong governance structures tighten managerial freedom and weak governance loosen it. Therefore, the total demand for resources is affected by the division of the universe of firms between strong and weak governance. In particular, a larger number of firms with weak governance implies more investment and a higher demand for resources, which results in a higher price of resources and a lower value of each firm with weak governance. In other words, the independent governance choices of individual firms affect the clearing of the resources markets, which in turn, feeds back into the profitability of each individual firm.

Our main result shows that the universe of firms will reach an equilibrium in which some firms have weak governance and other strong governance, but all firms will have the same value. A single firm and its shareholders, cannot increase the value of their firm by switching governance from weak to strong or the other way around; they are indifferent between these choices in equilibrium. Moreover, the competitive equilibrium is socially efficient in the sense that the allocation of resources cannot be improved, and in particular, a regulatory intervention is counterproductive. Importantly, we show that the governance structure is irrelevant when shareholders do not have perfect competence or market power in the ownership of multiple firms (i.e., common ownership), when firms do not have market power in the resources market, and when managers have meaningful career concerns. A violation of these conditions leads to governance relevance.

To understand the intuition behind the irrelevance of governance structure, note that the competitive resources market can clear in equilibrium only if the price is fair in the sense that investment is a zero net present value (NPV) from shareholders' perspective. For example, if investment is expected to be a negative NPV, shareholders will switch their firms from weak to strong governance as a means to deter managers from investment, thereby increasing their firm value. As a result, the demand for resources and their price will decrease. A lower price of resources implies a higher NPV on investment, and firms will continue switching from weak to strong governance until the NPV is zero. A symmetric argument explains why the investment cannot be a positive NPV either. Since investment must be a zero NPV in a competitive equilibrium, shareholders are indifferent between strong and weak governance, which is the reflection of the governance irrelevance. 
Our result has important implications for the study of corporate governance. First, since shareholders with market power in the ownership of multiple firms violate the irrelevance conditions, the model provides insights regarding the consequences of common ownership, and in particular, it explains the increasing demand by institutional investors for strong corporate governance in public firms. Our basic insight is that powerful common owners (such as BlackRock, Vanguard, and State Street) can enhance the value of their portfolios by increasing the mass of firms with strong governance above the competitive allocation. Since strong governance deters investment by managers, such policy lowers the demand for resources and reduces their price below the competitive level, thereby creating superior returns to the remaining weak governance firms. Essentially, common ownership breaks the irrelevance result because it can mitigate the negative price externality that weak governance firms impose on one another in the resources markets. However, common ownership might result in a socially inefficient outcome if it fails to internalize the alternative use of the resources by their suppliers. Importantly, our model suggests that common ownership might be harmful to the economy because of a monopsony power rather than a monopoly power.

Second, many predictions of the model are consistent with observed empirical patterns. For example, the model shows that due to common ownership, the increased returns in the capital markets (and the value of institutional investors' market-portfolios) come at the expense of lowering the returns in the labor market (De Loecker and Eeckhout 2017; Barkai 2018) and the input market, as well as reducing the overall level of investment in the economy (Furman and Orszag 2015, Gutiérrez and Philippon 2016). Moreover, the model shows that institutional investors' strategy of pushing more publicly traded firms to adopt strong governance might increase the returns to firms in the private market, and thus incentivizes private firms to stay private and public firms to go private (Doidge, Georg and Stulz 2016; EY report 2017).

Third, the model informs the design of empirical studies, showing that the hypothesis tying weak-governance to weak-performance is insufficient. And it shows the additional factors affecting the equilibrium: availability and competitiveness in the relevant resource's market, firms market power in the resources' markets, shareholders competence and market power in the ownership of firms, and the strength of managers' conflict and career concerns. Moreover, while governance is irrelevant in equilibrium, the model shows that when markets are out-of-equilibrium a portfolio of weak governance firms might outperform or underperform a 
portfolio of strong governance firms depending on the direction of the deviation from equilibrium. Thus, the design of an empirical study should account for corporate governance being both firm-specific and market-specific, and specify the market conditions under which it expects strong-governance to outperform weak-governance. Otherwise, misspecification is likely to result in inconclusive and conflicting findings.

Related Literature. Our paper is related to several strands of the literature on corporate governance. First, the theoretical literature has identified the tradeoff inherent in the allocation of control rights between "principal costs" and "agent costs" (Goshen and Squire 2017) and provided several channels through which the allocation of control rights to a principal is counterproductive. For example, by fostering managerial myopia (Stein 1988,1989), weakening agent's incentives to acquire information (Aghion and Tirole 1997) or share information (Adams and Ferreira 2007; Chakraborty and Yilmaz 2017; Harris and Raviv 2008,2010), undermining managerial initiatives (Burkart, Gromb, and Panunzi 1997), limiting the principal's ability to communicate with the agent (Levit 2018), or creating various distortions due to managerial career concerns (e.g., Hermalin and Weisbach 1998; Holmstrom 1999; and Zwiebel 1995). Our paper contributes to this literature by linking the allocation of control rights within firms to the resources market, and showing that the benefits of empowering shareholders is offset by its costs in a competitive equilibrium; which implies the irrelevance of corporate governance. Our theory highlights the importance of real markets in resolving the various trade-offs of corporate governance.

Second, our paper contributes to the theoretical literature on common ownership (e.g., see Admati, Pfleiderer and Zechner 1994; Azar 2017; Edmans, Levit and Reilly 2018; Gilje, Gormley and Levit 2018; Hansen and Lott 1996; Kraus and Rubin 2010; Lopez and Vives forthcoming; O'Brien and Salop 2000; Rubin 2006). Different from these studies, however, common ownership in our model creates a monopsony power because firms are linked through the resources market. Importantly, the underlying mechanism in our model does not require tacit collusion or coordination between managers in different firms, nor does it require common owners to exercise their control rights in a manner that is inconsistent with maximizing the value of each individual firm in their portfolio. Finally, our model contributes to the literature on governance externalities (Acharya and Volpin 2010; Dicks 2012; Acharya, Gabarro, and Volpin 2013; Burkart and Raff 2014; Nielsen 2006; Cheng 2011; Levit and Malenko 2016) by identifying a 
novel channel of externalities that works through a competitive resource market, and as such, gives rise to new implications and empirical predictions.

The remainder of the paper is organized as follows. In Section 2, we present the baseline model, in Section 3, we present the model's analysis, in Section 4, we analyze the extensions to the model, in Section 5, we discuss the implications of our results for common ownership and the design of empirical studies, and in Section 6 we conclude with final remarks.

\section{Model Setup}

Consider an economy with a mass of $N>0$ ex-ante identical firms, indexed by $i$. Each firm is run by a manager and owned by a representative shareholder. The manager of firm $i$ owns a fraction $\omega \in(0,1)$ of the firm's cash flows rights; the rest is owned by the shareholder.

Each manager can either keep the status quo of his firm $\left(x_{i}=0\right)$ or change it $\left(x_{i} \neq 0\right)$. For example, changing the status quo involves the acquisition of another company, whereas keeping the status quo represents internal growth. If the manger keeps the status quo then the value of the firm is $v>0$. If the manager changes the status quo then she has to choose between two mutually exclusive projects, denoted by $x_{i} \in\{A, B\}$. The gross return from investment in project $\mathrm{A}$ and $\mathrm{B}$ is $v+R_{A}$ and $v-R_{B}$, respectively, where $R_{A}>0$ and $R_{B}>0$. Since project A increases value while project B decreases value, shareholders prefer project A over project B. For example, project $\mathrm{A}$ is an acquisition of a firm with which there are substantial synergies, whereas project $\mathrm{B}$ is a value-destroying acquisition.

Changing the status quo of the firm, however, requires investment of resources. Resources are provided by what we can call "suppliers." The resources can be skilled employees, raw materials, intellectual property, other firms that can be acquired, or anything that can be used for new business activity. We assume a competitive market for these resources, and denote by $p$ their market price. Therefore, under project $\mathrm{A}$, firm value is $v+R_{A}-p$, and under project $\mathrm{B}$ firm value is $v-R_{B}-p$. Notice that the price of resources needed for investment in projects $\mathrm{A}$ and $\mathrm{B}$ is the same, as the market cannot distinguish between these two projects.

The manager of each firm is either loyal or disloyal. We denote the type of firm $i^{\prime} s$ manager by $\theta_{i} \in\{$ loyal, disloyal $\}$, and assume it is identically and independently distributed across firms. The prior probability a manager is loyal is $\lambda \in(0,1)$. Disloyal managers obtain private 
benefits $b>0$ from investment in project B. There are no private benefits from investment in project A. Loyal managers have no private benefits from either project, although they can still invest in project B if they wish to. As an alternative interpretation, loyal managers can derive private benefits from project $B$, but their moral standards are high enough to prevent them from driving private benefits while damaging shareholders. ${ }^{11}$ For example, project A is the acquisition of a firm with which the company is likely to have operational synergies. Project B is the acquisition of a firm that is unlikely to yield any synergy, however, it may personally benefit the manager by satisfying his empire-building aspirations or by reducing the idiosyncratic risk of the company (i.e., diversifying acquisition). We assume that the private benefits of a disloyal manager are large relative to his cash-flows rights,

$$
b / \omega>R_{A}+R_{B}
$$

This assumption guarantees that, everything else held equal, disloyal managers prefer project B over project A. Without this assumption, managers have no conflict of interest with their shareholders, and without any conflict, the allocation of control rights will be irrelevant. We therefore rule out these trivial cases.

Remark. The source of unobserved heterogeneity among managers in our model can be interpreted as incompetence rather than disloyalty. A disloyal manager can be considered incompetent in the sense that he must incur a private cost $(b)$ to invest in a value-increasing project such as project A. Similarly, a loyal manager can be considered competent in the sense that she can invest in project $\mathrm{A}$ without incurring additional costs. Our analysis is invariant to such reinterpretation.

\section{Timeline}

1. Allocation of control rights. At the outset, the shareholder of firm $i$ chooses $c_{i} \in$ $\{S H, M\}$. If $c_{i}=S H$ then the shareholder has the right to fire its manager as we describe below. If $c_{i}=M$ then the shareholder does not have this right. We will often refer to firms with $c_{i}=M$ as firms with weak governance, and firms with $c_{i}=S H$ as firms with strong

\footnotetext{
${ }^{11}$ Note that a loyal manager still maximizes his own value while taking into account all considerations, including career concerns which we later describe.
} 
governance. For example, firms with weak governance are firms with dual-class shares, or firms with staggered boards and poison pills. All shareholders make their governance decisions simultaneously, and these decisions become public. In Section 4.5 we discuss a variant of the model in which the choice of $c_{i}$ is an outcome of negotiations between the manager and the shareholder of firm $i .^{12}$

2. Operating period. The manager of each firm privately observes her type $\theta_{i}$ and decides on $x_{i} \in\{0, A, B\}$. Managers make their decisions simultaneously. The price of resources, $p$, is determined by market clearing, that is, demand equals supply. Suppliers are willing to sell their resources if and only if their alternative use of resources is smaller than the market price. We assume that the mass of suppliers whose alternative use of resources is smaller than $p$ is $K(p) \geq 0$, where $K^{\prime}(\cdot)>0$ and $K(\underline{p})=0$ for some $\underline{p}>0$. We further assume

$$
0<K\left(\lambda R_{A}-(1-\lambda) R_{B}\right)<N
$$

which guarantees that the supply of resources is not too scarce or too abundant. The role of this assumption is discussed in greater details in the analysis below and in Section 4.4.

3. Realization of interim signal. The shareholder of firm $i$ observes whether the manager keeps the status quo $\left(x_{i}=0\right)$ or changes it $\left(x_{i} \in\{A, B\}\right)$, but she cannot directly distinguish between projects $\mathrm{A}$ and $\mathrm{B}$. If the manager keeps the status quo then the shareholder does not receive additional information about the manager's loyalty. Intuitively, managing the firm under the status quo does not require extraordinary actions, and as such, it does not produce new information about the manager. However, if the manager changes the status quo, then the shareholder observes an additional signal $s_{i} \in\{A, B\}$, where

$$
\operatorname{Pr}[s=x \mid x \in\{A, B\}]=\tau \in(0.5,1) .
$$

Parameter $\tau$ is the signal's precision, and it can be interpreted as the shareholder's ability to understand in real time, once the status quo is changed, whether the actions that are taken

\footnotetext{
${ }^{12}$ To focus attention on the division of control rights rather than cash-flows rights, parameter $\omega$ is assumed to be exogenous. The trade-off related to $\omega$ is intuitive: a larger $\omega$ aligns the incentives of the manager with the shareholder, but it leaves the shareholder with less ownership in the firm. We effectively assume that shareholders offers the lowest $\omega$ that is acceptable by the manager subject to conditions (1) and (4).
} 
by the manager create shareholder value (if project $\mathrm{A}$ is chosen) or destroy it (if project $\mathrm{B}$ is chosen). ${ }^{13}$ Notice that the shareholder does not learn directly about the manager's loyalty; signal $s$ provides information about $\theta_{i}$ only if the manager's choice between projects $\mathrm{A}$ and $\mathrm{B}$ is correlated with her loyalty. Also notice that the shareholder can never rule out the possibility that the signal is wrong (i.e., $\tau<1$ ). This assumption is further discussed in Section 4.3.

4. Exercising control. After the manager makes her decision and the shareholder obtains the signal (whenever $x_{i} \neq 0$ ), the manager can be fired by the shareholder if $c_{i}=S H .{ }^{14}$ We denote by $e_{i}=$ fire the event in which manager $i$ is fired and by $e_{i}=$ retain the event in which she is retained. If the incumbent manager is fired, then the loyalty of the new manager is drawn independently from the same distribution as the incumbent (i.e., the new manager is loyal with probability $\lambda$ ). The shareholder's continuation value from retaining a manager is $\Lambda>0$ if the manager is loyal, and zero otherwise. This assumption captures in a reduced form the relative benefit to shareholders from having their firm run by a loyal manager. If the shareholder is indifferent between firing and retaining the incumbent manager, then the manager is retained (e.g., there are small replacement costs). The additional payoff to the incumbent manager from keeping her job is $\Gamma>0$. Parameter $\Gamma$ measures in a reduced form the strength of managerial career concerns. We assume that these career concerns are sufficiently important, that is,

$$
\Gamma>\Gamma^{*} \equiv \omega \max \left\{\frac{R_{A}-\underline{p}}{1-\tau}, b / \omega-R_{B}-\underline{p}\right\} .
$$

The role of Assumption (4) will become clear in the analysis below, and it is further discussed in Section 4.2. Finally, upon replacement, the new manager gets a utility of $\Gamma$, and the incumbent manager receives his outside option which is normalized to zero. Therefore, there are no welfare gains or losses from replacing the incumbent manager that are not related to his loyalty.

\footnotetext{
${ }^{13}$ Note that at the end of the game, the shareholder can perfectly infer the choice of the manager between projects $\mathrm{A}$ and $\mathrm{B}$. The analysis, however, would not change if the payoffs from the projects are stochastic. In particular, we can interpret $v-R_{B}-p$ and $v+R_{A}-p$ as the expected payoffs from project $\mathrm{B}$ and A, respectively. The realized payoff of each project could be high or low, and in this case, the shareholder will not be able to perfectly infer from the final outcomes the actual choice of the manager.

${ }^{14}$ In practice, shareholders do not vote directly on the replacement of CEO, it is the responsibility of the board of directors. Here we assume that the board will maximize the value of the shareholders, subject to the constraints given by the governance rule of the firm. Alternatively, one can relabel the manager with the board, and interpret the problem as shareholders' decision to oust directors.
} 
5. Distribution of payoffs. All shareholders and managers are risk neutral. ${ }^{15}$ The shareholder's payoff is

$$
u_{S H}\left(\theta_{i}, x_{i}, e_{i}\right)=(1-\omega) r\left(x_{i}\right)+\Lambda \cdot\left[\mathbf{1}_{e_{i}=\text { retain } \text { and } \theta_{i}=\text { loyal }}+\mathbf{1}_{e_{i}=\text { fire } \text { and } \theta_{i}^{\prime}=\text { loyal }}\right],
$$

where, $\mathbf{1}$ is an indicator function, $\theta_{i}^{\prime}$ is the type of the new manager, and

$$
r\left(x_{i}\right) \equiv v+\mathbf{1}_{x_{i}=A} \cdot\left(R_{A}-p\right)-\mathbf{1}_{x_{i}=B} \cdot\left(R_{B}+p\right) .
$$

The incumbent manager's payoff is

$$
u_{M}\left(\theta_{i}, x_{i}, e_{i}\right)=\omega r\left(x_{i}\right)+b \cdot \mathbf{1}_{x_{i}=B \text { and } \theta_{i}=\text { disloyal }}+\Gamma \cdot \mathbf{1}_{e_{i}=\text { retain }}
$$

Figure 1 summarizes the timeline of the model.

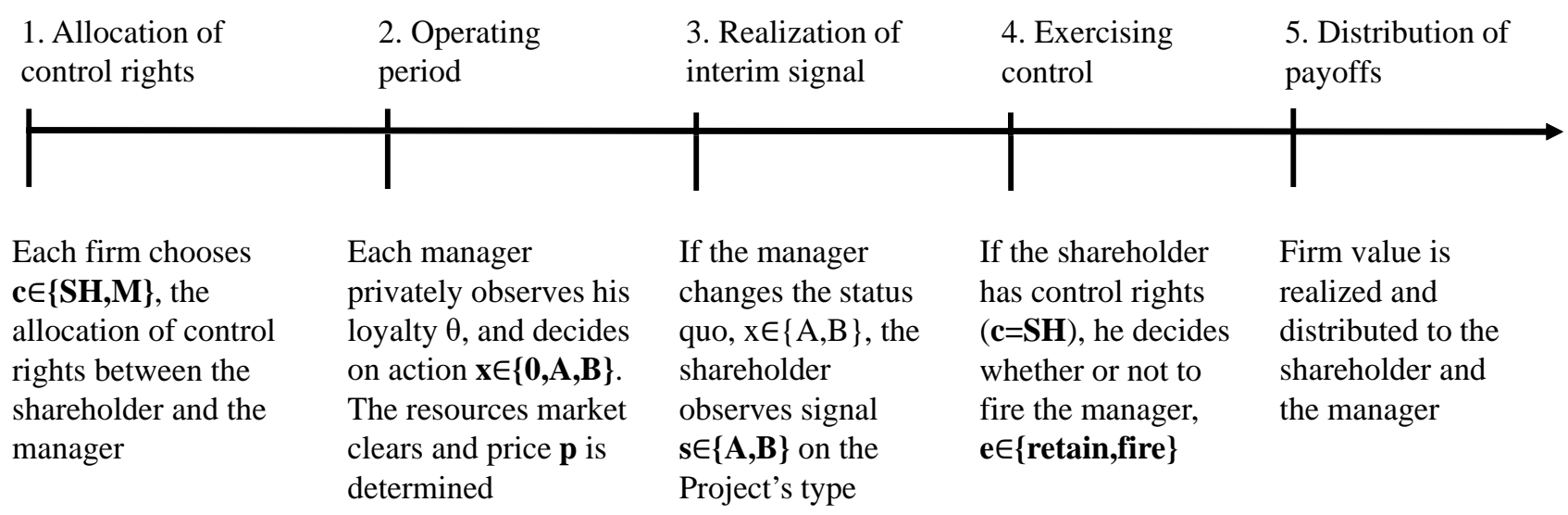

Figure 1 - timeline

\section{Analysis}

The goal of the analysis is to identify the conditions under which the expected shareholder value is invariant to the allocation of control rights. When these conditions are met, the structure of

\footnotetext{
${ }^{15}$ The assumption on risk-neutrality is for simplicity and it does not derive our main result.
} 
the firm's corporate governance is irrelevant. ${ }^{16}$

We proceed as follows: Section 3.1 characterizes the equilibrium of the baseline model, Section 3.2 presents our main result about governance irrelevance, and Section 3.3 discusses the welfare implications. In Section 4 we discuss the robustness of our main result to various permutations of the model, as well as the conditions under which the governance structure becomes relevant.

\subsection{Equilibrium Characterization}

The solution concept we adopt is a Perfect Bayesian Equilibrium in pure strategies that satisfies the Grossman and Perry (1986) criterion. This refinement selects a unique equilibrium of the game. For simplicity, we refer to an equilibrium that meets this condition as a competitive equilibrium.

We start by analyzing the behavior of an individual firm given its governance structure $\left(c_{i}\right)$, the price of resources $(p)$, and the allocation of control rights in all other firms. Notice that given $c_{i}$ and $p$, the behavior of firm $i$ does not depend on the allocation of control rights in other firms or the actions of their managers. Once we establish the behavior of individual firms, we solve for the allocation of control rights and the market clearing price in equilibrium.

Consider first the analysis of firms with weak governance. If $c_{i}=M$ then shareholder $i$ does not have the right to fire the manager of his firm. Without the threat of being fired, a loyal manager never chooses project $\mathrm{B}$, and she prefers project $\mathrm{A}$ over the status quo if and only $\omega\left(v+R_{A}-p\right)+\Gamma \geq \omega v+\Gamma$, which is equivalent to $p \leq R_{A}$. By contrast, a disloyal manager has private benefits from investment in project B. Since $b / \omega-R_{B} \geq R_{A}$, the disloyal manager always prefers project $B$ over project $A$, and he prefers project B over the status quo if and only $b+\omega\left(v-R_{B}-p\right)+\Gamma \geq \omega v+\Gamma$, which is equivalent to $p \leq b / \omega-R_{B}$. The next result summarizes these observations. All proofs not in the main text are given in Appendix A.

Lemma 1 Suppose the price of resources is $p$ and firm $i$ has weak governance $\left(c_{i}=M\right)$. Then, an equilibrium exists and satisfies the following: the loyal manager invests in project $A$ if $p \leq R_{A}$ and keeps the status quo otherwise, and the disloyal manager invests in project $B$ if $p \leq b / \omega-R_{B}$ and keeps the status quo otherwise.

\footnotetext{
${ }^{16}$ See Section 4.5 for a discussion on how our main result might change if the irrelevance of corporate governance is measured with respect to the shareholder value plus managerial private benefits.
} 
The next result shows that the actions of managers in firms with strong governance is fundamentally different from the actions of managers in firms with weak governance.

Lemma 2 Suppose the price of resources is $p$ and firm $i$ has strong governance $\left(c_{i}=S H\right)$. Then, an equilibrium exists and satisfies the following: the manager keeps the status quo regardless of his loyalty, and he is not fired on the equilibrium path. Off the equilibrium path, if the manager changes the status quo, then the shareholder believes the manager is disloyal and he fires him with probability one.

Lemma 2 shows that when the shareholder has the right to fire the manager, the manager always keeps the status quo in equilibrium. Intuitively, recall the shareholder fires the manager only if the shareholder obtains an indication that the manager is more likely to be disloyal than a potential replacement. Such indication is obtained upon a change to the status quo. In particular, the shareholder can be confident that a loyal manager will not choose project B, and a disloyal manager will not choose project A. Therefore, a signal $s=B$ is an indication that the manager is disloyal, and the shareholder has the incentive to fire the manager in those cases. The fear from this possibility deters the disloyal manager from choosing project B. Specifically, the manager's career concerns (i.e., $\Gamma>\Gamma^{*}$ ) guarantee that she will try to avoid the possibility of being fired, even if it means forgoing investment in project $\mathrm{B}$ and the associated private benefits. Similarly, a loyal manager will be deterred from choosing project A. Indeed, since $\tau<1$, there is always a possibility that the shareholder will get the wrong signal (i.e., $s_{i}=B$ even though $x_{i}=A$ ) and mistakenly fire the loyal manager. In equilibrium, the manager finds a safe heaven in keeping the status quo of the firm. If the manager keeps the status quo regardless of her loyalty, then the shareholder does not learn new information about the manager's loyalty, and thus has no reason to fire her.

Lemmas 1 and 2 show that the allocation of control rights affects managers' actions, and therefore, has a potential effect on the expected shareholder value. In equilibrium, the shareholder of each firm chooses the governance structure that maximizes his expected value, taking as given the expected behavior of shareholders and managers in other firms. Seemingly, the governance structure is relevant. However, the consequences of managers' actions on the shareholder value also depend on market forces, that is, the equilibrium price of resources. If governance affects managers' actions, it will also have an indirect effect on prices through the 
market clearing process. Accounting for this dynamics, the next result fully characterizes the equilibrium of the game.

Proposition 1 A generically unique equilibrium exists. ${ }^{17}$ In equilibrium, the price of resources $i s$

$$
p^{*}=\lambda R_{A}-(1-\lambda) R_{B}
$$

a mass of $n^{*} \equiv K\left(p^{*}\right) \in(0, N)$ firms adopt weak governance, and a mass of $N-n^{*}$ firms adopt strong governance. Moreover:

(i) In firms with weak governance $\left(c_{i}^{*}=M\right)$, the loyal manager chooses project $A$ and the disloyal manager chooses project $B$.

(ii) In firms with strong governance $\left(c_{i}^{*}=S H\right)$, the actions of managers and shareholders is characterized by Lemma 2.

Proposition 1 characterizes the price of resources in equilibrium, as well as the number of firms that adopt strong governance. The characterization of managerial actions follows directly from Lemmas 1 and 2. Notice that the price of resources in equilibrium, which is given by Expression (7), is smaller than $R_{A}$. Since $p^{*}<R_{A}<b / \omega-R_{B}$, managers change the status quo of their firms if and only if the governance of their firm is weak. Therefore, the demand for resources equals the mass of firms with weak governance. At the same time, if the price of resources in equilibrium is given by Expression (7), then the supply of these resources must be $K\left(p^{*}\right)$. Therefore, the market clears only if exactly $K\left(p^{*}\right)$ firms adopt weak governance. Assumption (2) ensures an interior solution, that is, $K\left(p^{*}\right) \in(0, N)$. This logic explains why the number of firms that adopt weak governance in equilibrium is as stated by Proposition 1.

The arguments above, however, do not explain how the price of resources is determined in equilibrium. In equilibrium, shareholders of firms with weak governance must not benefit from switching to strong governance, and vice-versa. Since firms are price-takers, all shareholders must be indifferent with respect to the corporate governance of their firms. Otherwise, all firms will adopt the same corporate governance. If on the contrary all firms adopt strong governance, then according to Lemma 2, no manager will change the status quo. With no

\footnotetext{
${ }^{17}$ The equilibrium is generically unique in the sense that it does not pin down the identity of the firms that choose $c_{i}^{*}=M$, only their total mass. In addition, other off-equilibrium beliefs can support this equilibrium.
} 
demand for resources, their price must be $\underline{p}$. However, such a low price presents an opportunity for firms with strong governance to obtain positive abnormal returns. Indeed, by switching to weak governance, managers are assured they will not be fired by shareholders, thereby inducing a profitable change to the status quo of the firm. Therefore, in equilibrium, some firms must choose weak governance. Similarly, if on the contrary all firms adopt weak governance, then according to Lemma 1, managers will change the status quo of their firms, and the demand for resources will be very high. Assumption (2) guarantees a scarce supply of resources and a high price in those circumstances. If the price of resources is too high, shareholders would benefit from switching to strong governance as a means to deter managers from pursuing valuedestroying changes to the status quo of their firm. Therefore, in equilibrium, some firms must choose strong governance. Overall, the equilibrium is characterized by a subset of firms which adopt weak governance and a complement set of firms which adopt a strong governance structure.

The price $p^{*}=\lambda R_{A}-(1-\lambda) R_{B}$ has the unique property of keeping shareholders indifferent between weak and strong governance under the expected behavior of managers. Specifically, under a strong governance structure, the manager keeps the status quo of the firm, and the expected shareholder value is

$$
(1-\omega) v+\lambda \Lambda .
$$

Under a weak governance structure, the manager changes the status quo as described by part (i) of Proposition 1, and the expected shareholder value is

$$
(1-\omega)\left[\lambda\left(v+R_{A}-p^{*}\right)+(1-\lambda)\left(v-R_{B}-p^{*}\right)\right]+\lambda \Lambda .
$$

Indeed, since $p^{*}<R_{A}$, a loyal manager chooses project $\mathrm{A}$ and creates a value of $v+R_{A}-p^{*}$, and a disloyal manager chooses project $\mathrm{B}$ and creates a value of $v-R_{B}-p^{*}$. Expression (9) is the weighted average of these valuations, given the shareholder's prior on the manager's loyalty. A comparison between Expressions (8) and (9) reveals that they are identical if and only if $p^{*}=\lambda R_{A}-(1-\lambda) R_{B}$. The indifference of shareholders between weak and strong governance in equilibrium implies that the price of resources must be given by Expression (7). 


\subsection{Irrelevance of Governance Structure}

Building on Proposition 1, we are now ready to state our main result.

Theorem 1 The corporate governance structure is irrelevant, namely, in a competitive equilibrium the expected shareholder value in each firm is invariant to the firm's allocation of control rights.

Theorem 1 states that, in equilibrium, shareholders are indifferent between strong and weak corporate governance, and therefore, this choice is irrelevant at the firm level. In other words, the theory predicts that one should not expect to observe a change to the shareholder value if, everything else held equal, the firm's corporate governance structure changes exogenously.

Essentially, the irrelevance is obtained because in equilibrium market clearing requires the price of resources to be fair in the sense that a change to the status quo is a zero net present value (NPV) investment from the shareholders' perspective. If, to the contrary, strong governance increases (decreases) shareholder value in equilibrium, it must be that a change to the status quo is a negative (positive) NPV. If so, more and more shareholders will switch their firms to strong (weak) governance as a means to induce managers to maintain (change) the status quo. As a result, the demand for resources will decrease (increase), and consequently, so will their price. A lower (higher) price of resources implies a higher (lower) NPV to a change to the status quo. Firms will continue switching to strong (weak) governance as long as the NPV is negative (positive). For this reason, in equilibrium, the NPV must be zero, which implies that shareholders are indifferent between strong and weak governance.

Remark. Theorem 1 does not suggest that the aggregate level of corporate governance is irrelevant. Indeed, Proposition 1 characterizes the unique number of firms with strong governance in equilibrium. This number depends on features of the resources market (i.e., the supply function $K(\cdot)$ ), the payoffs of good and bad projects (i.e., $R_{A}$ and $R_{B}$ ), as well as the likelihood that managers are loyal (i.e., $\lambda$ ). Since these characteristics could vary across economies and industries, the aggregate level of corporate governance, denoted by $n^{*}$, could also differ in the cross-section. 


\subsection{Welfare Implications}

\subsubsection{Social Welfare}

In this section we study whether regulators can improve social welfare by changing the balance of power between shareholders and managers. While a regulator has the power to determine the allocation of control rights in every firm, we assume that a regulator cannot directly determine the price of resources or force managers to choose between project A, project $\mathrm{B}$, and the status quo. Obviously, such unimaginable power would improve social welfare above and beyond what is obtained in the competitive equilibrium.

The expected social welfare in the competitive equilibrium, which is characterized by Proposition 1 , is given by

$$
W^{*}=N v+K\left(p^{*}\right) p^{*}+\int_{p^{*}}^{\infty} y d K(y)+N \Gamma+N \lambda \Lambda .
$$

The first term, $N v$, is the baseline value of all firms. The second term, $K\left(p^{*}\right) p^{*}$, is the additional expected value created to shareholders by firms with weak governance, gross of the resources price (which is a transfer between firms and suppliers). Recall that $K\left(p^{*}\right)$ firms adopt weak governance in equilibrium. Firms with weak governance choose project $\mathrm{A}$ whenever their manager is loyal (which happens with probability $\lambda$ ) and project $\mathrm{B}$ whenever their manager is disloyal (which happens with probability $1-\lambda$ ). Therefore, the additional expected value created by these firms is $p^{*}=\lambda R_{A}-(1-\lambda) R_{B}$, which is the price of resources in a competitive equilibrium. The third term, $\int_{p^{*}}^{\infty} y d K(y)$, is the alternative valuation of the resources by suppliers who did not sell in equilibrium. Indeed, in equilibrium, suppliers retain their resources if and only if the alternative use of these resources is higher than the market price $p^{*}$. The fourth term, $N \Gamma$, is the value of managers from retaining their job (recall manages are never fired on the equilibrium path). The fifth term, $N \lambda \Lambda$, is the continuation value to shareholders from retaining their managers. This explains the expression behind $W^{*}{ }^{18}$

The next result shows that the competitive allocation of control rights maximizes the expected social welfare subject to the constraints we outlined above.

\footnotetext{
${ }^{18}$ Notice that the social welfare function does not account for managerial private benefits. If it did, then the socially optimal allocation would require more firms with weak governance relative to the competitive allocation (so disloyal manager who choose project B can enjoy these private benefits). See Section 4.5 for related discussion.
} 
Proposition 2 The competitive equilibrium allocation of control rights, $n^{*}$, is socially efficient.

Proposition 2 implies that in the context of our model, a regulatory intervention would be counterproductive. Intuitively, the competitive allocation ensures that a change to the status quo is a zero NPV investment. In particular, the alternative value of the marginal supplier who sells his asset in equilibrium is given by $p^{*}=\lambda R_{A}-(1-\lambda) R_{B}$. On the other hand, relative to a firm with strong governance (which always keeps the status quo), the expected social value that is created by a firm with weak governance is $\lambda\left(v+R_{A}\right)+(1-\lambda)\left(v-R_{B}\right)-v$. Since the two terms are identical, the regulator cannot increase social welfare by changing the allocation of control rights across firms.

\subsubsection{Aggregate Shareholder Value and Common Ownership}

In this section we characterize the allocation of control rights that maximizes the value of shareholders on aggregate. That is, suppose shareholders of all firms could coordinate their decision-making, would they benefit as a whole from changing the competitive allocation? This question is motivated by the steep growth of large asset managers in the United States (e.g., BlackRock, Vanguard, State Street, and others) which own a large equity stake in virtually every publicly traded company.

A direct implication of Proposition 2 is that any deviation from the competitive allocation is socially inefficient. Therefore, to the extent that large asset managers benefit from changing the competitive allocation, it would be socially undesirable. But does BlackRock, as an example, have incentives to change the competitive allocation? The next result clarifies that the answer to this question could be positive.

Proposition 3 The allocation of control rights that maximizes the aggregate shareholder value requires the number of firms with weak governance to be strictly smaller than $n^{*}$, the competitive allocation. Under this allocation, the price of resources is strictly smaller than $p^{*}$, the competitive price, and the expected shareholder value of firms with weak governance is strictly greater than the expected shareholder value of firms with strong governance.

To understand Proposition 3, notice that a direct implication of Theorem 1 is that under the competitive allocation, the expected value of each firm (net of the value of retaining loyal 
managers) is $v$ regardless of the strength of its governance or the price of resources. Since the expected shareholder value of firms with strong governance is always $v$, a change in the allocation can be beneficial only if it increases the expected shareholder value of firms with weak governance.

Consider a policy of BlackRock that increases the mass of firms with weak governance above the competitive allocation. Since firms with weak governance are more likely to change the status quo, such policy creates more demand for resources, and as a result, increases the market price paid by all firms with weak governance. Therefore, the value of firms with weak governance under this alternative allocation must be lower than their value under the competitive allocation. As a result, such a policy is undesirable from the perspective of a shareholder who holds the market portfolio, like BlackRock.

However, BlackRock can enhance the value of its market portfolio by increasing the mass of firms with strong governance above the competitive allocation. Such policy will create less demand for resources (and therefore, less investment) by deterring more managers from changing the status quo of their firms. As a result, the market price of resources will decrease below its competitive level, and the value of remaining weak governance firms will increase. In other words, by pushing more firms to adopt strong governance, BlackRock mitigates the negative price externality that firms with weak governance impose on one another when changing their status quo, thereby creating abnormal returns to firms with weak governance. The optimal policy from BlackRock's perspective will trade off a lower number of weak governance firms in its portfolio with a higher abnormal profit for each of these firms. ${ }^{19}$ This policy, however, is socially inefficient since BlackRock does not internalize the social benefit that occurs when firms with weak governance buy the resources from suppliers whose alternative use of these assets is lower than the value that can be generated by those firms. In Section 5 below we will elaborate on common ownership and its consequences.

\footnotetext{
${ }^{19}$ In the proof of Proposition 3 we show that the allocation that maximizes total expected shareholder value solves $\max _{n \in\left[0, n^{*}\right]} n\left(\lambda\left(R_{A}-K^{-1}(n)\right)-(1-\lambda)\left(R_{B}+K^{-1}(n)\right)\right)$.
} 


\section{Extensions}

In this section we discuss the assumptions that are key for the governance irrelevance result. Highlighting the importance of these assumptions will also clarify under what conditions our model predicts that the corporate governance is relevant. Omitted proofs can be found in Appendix B.

\subsection{Market Power}

In the baseline model firms are price-takers, namely, the demand of a single firm cannot change the market clearing price of resources. This assumption is a key force behind the governance irrelevance in Theorem 1, which is a reminiscent of the indifference of shareholders between strong and weak governance in the competitive equilibrium. However, when a firm has market power, a change of its governance structure from strong to weak will increase the aggregate demand for resources and their price. Shareholders of firms with market power and strong governance internalize this effect on the expected value of the firm, and as a result, might be strictly worse off by adopting a weak governance structure. In equilibrium, shareholders might not be indifferent, and firms with weak governance could outperform firms with strong governance. ${ }^{20}$ In other words, the governance structure can be relevant when firms have market power.

Nevertheless, even with market power, the incentive of shareholders to choose the governance structure that maximizes the value of their firm limits the outperformance of firms with weak governance in equilibrium. Specifically, recall that if the demand for resources is $n$, then the price that clears the market is $K^{-1}(n)$. It can be shown that, with market power, the number of firms with weak governance in equilibrium, denoted by $n^{*}$, must satisfy

$$
K^{-1}\left(n^{*}\right) \leq \lambda R_{A}-(1-\lambda) R_{B} \leq K^{-1}\left(n^{*}+1\right)
$$

Intuitively, the left (right) inequality guarantees that firms with weak (strong) governance do

\footnotetext{
${ }^{20}$ Notice that this effect is asymmetric. Namely, shareholders of firms with weak governance which switch to strong governance can expect the price of resources to decrease, however, since firms with strong governance maintain the status quo, the negative pressure on the price does not affect the considerations of these shareholders.
} 
not benefit from switching to strong (weak) governance. Moreover, Condition (11) implies that the price of resources in equilibrium, $K^{-1}\left(n^{*}\right)$, cannot be too different from the competitive price, which according to Proposition 1 is given by $\lambda R_{A}-(1-\lambda) R_{B}$. The outperformance of firms with weak governance is therefore given by $\lambda R_{A}-(1-\lambda) R_{B}-K^{-1}\left(n^{*}\right)$, and according to Condition (11), it is bounded by $K^{-1}\left(n^{*}+1\right)-K^{-1}\left(n^{*}\right)$. The latter term is the price impact of a single firm on the price of resources, and can be thought of as a measure of its market power. A larger market power implies a higher scope for outperformance of firms with weak governance in equilibrium.

\subsection{Weak Managerial Career Concerns}

The irrelevance of corporate governance requires managers to be sufficiently concerned about the implications of their present actions on the prospects of their career. The model captures these career concerns in a reduced form by parameter $\Gamma$, and requires it to be larger than $\Gamma^{*}$, as defined by the Expression in (4). The cutoff $\Gamma^{*}$ is determined such that the manager, regardless of his loyalty, would rather avoid the risk of being fired even at the "price" of keeping the status quo of the firm. ${ }^{21}$ In other words, we require corporate governance to affect real outcomes, not just the identity of the executive in office. Since corporate governance affects real outcomes, there is a link between the corporate governance and the demand for resources, and the market for resources clears only if shareholders are indifferent between strong and weak governance. Therefore, this link is crucial for the irrelevance of corporate governance.

To emphasize this point, suppose $\Gamma=0$. In this extreme case, the manager is indifferent to the shareholder's decision to fire her, and therefore, the manager's behavior is unaffected by the allocation of control rights. In particular, if $\Gamma=0$ then the manager's behavior would be characterized by Lemma 1, whether the governance is strong or weak. In equilibrium, the resources market must still clear, but the market clearing condition will be determined by the manager's indifference rather than the shareholder's indifference. That is, the aggregate allocation of control will not have an effect on the price of resources. Moreover, it follows from

\footnotetext{
${ }^{21}$ Specifically, assuming $\Gamma / \omega>b / \omega-R_{B}-p$ guarantees that the disloyal manager prefers the status quo and keeping his job if he expects to be fired upon choosing project $B$, even if the price of the project is the lowest possible, $\underline{p}$. Assuming $\Gamma / \omega>\frac{R_{A}-\underline{p}}{1-\tau}$ guarantees that the loyal manager prefers the status quo and keeping his job if he expects to be fired upon choosing project A with probability $1-\tau$, even if the price of the project is the lowest possible, $\underline{p}$.
} 
Lemma 1 that the decision of the manager will provide shareholders with new information about the manager's loyalty, and as a result, the option to fire the manager would be valuable. For example, if in equilibrium $p<R_{A}$, then a combination of a change to the status quo and signal $s=B$ reveals that the manager is likely to be disloyal, and the shareholder will benefit from firing the manager. Therefore, strong corporate governance will maximize the shareholder value not because it disciplines the manager's behavior, but rather, because it allows the shareholder to appoint better managers going forward.

Overall, if managers have weak career concerns (i.e., $\Gamma=0$ ) then shareholders will prefer strong governance and, relative to weak governance, strong governance will generate abnormal returns to shareholders from the option to fire the manager. Corporate governance will be relevant.

\subsection{Perfect Shareholder Competence}

The irrelevance of corporate governance requires shareholders to be somewhat incompetent in the sense that their signal about the manager's actions cannot be perfect, that is, $\tau<$ 1. Intuitively, if $\tau=1$ then the loyal manager does not face the risk of being fired by the shareholder after choosing project $\mathrm{A}$; the shareholder will always recognize that indeed project A was chosen. Similarly, the disloyal manager can be certain that if he chooses project B then the shareholder will notice it and will consequently fire him. As long as the managerial career concerns are sufficiently large (as we assume in the baseline model), the disloyal manager will avoid the risk of being fired by pooling with the loyal manager. However, unlike the baseline model, since the loyal manager does not face the risk of being fired following a choice of project A, the pooling will be on project A rather than on the status quo. As a result, shareholders will strictly prefer strong governance as a means to deter disloyal managers from choosing project B. For this reason, corporate governance is relevant if shareholders have perfect competence.

\subsection{Extreme Supply of Resources}

Our result of governance irrelevance depends on Condition (2), which guarantees that the supply of resources needed for changing the status quo is neither too scarce nor too abundant. To see more clearly why, note that if $K\left(\lambda R_{A}-(1-\lambda) R_{B}\right)<0\left(K\left(\lambda R_{A}-(1-\lambda) R_{B}\right)>N\right)$ then the 
supply of resources is too scarce (abundant) and an equilibrium in which all shareholders choose strong (weak) governance exists. Indeed, $K\left(\lambda R_{A}-(1-\lambda) R_{B}\right)<0\left(K\left(\lambda R_{A}-(1-\lambda) R_{B}\right)>\right.$ $N$ ) implies that the price of resources that clears the market is always greater (smaller) than $\lambda R_{A}-(1-\lambda) R_{B}$. Therefore, it follows from Lemma 1 that the expected shareholder value in firms with weak governance is smaller (greater) than $(1-\omega) v+\lambda \Lambda$. Recall that according to Lemma 2, managers in firms with strong governance maintain the status quo, and as a result, the expected shareholder value in those firms is $(1-\omega) v+\lambda \Lambda$. Therefore, all shareholders would prefer strong (weak) governance. In this respect, when the supply of resources is too scarce or too abundant, the governance structure is relevant. ${ }^{22}$

\subsection{Negotiated Governance Arrangements}

In our baseline model, the irrelevance of governance is with respect to shareholder value. The private benefits of the manager are excluded from the consideration of shareholders whether to adopt a strong or a weak governance. In general, however, when setting the corporate governance of the firm, shareholders might negotiate the governance structure with the manager. Without other frictions (e.g., asymmetric information about the manager's type at the negotiation stage), the negotiation process will obtain the outcome that maximizes the surplus of the shareholders and the manager combined. ${ }^{23}$ Under this alternative assumption, the choice of corporate governance should also internalize the additional private benefits of disloyal managers from project $\mathrm{B}$.

Under this alternative assumption, corporate governance will be irrelevant with respect to the total firm value, for the same reasons as in the baseline model. Indeed, the expected firm value under strong governance is $v+\lambda \Lambda$, and under weak governance it is

$$
\lambda\left(v+R_{A}-p^{*}\right)+(1-\lambda)\left(v-R_{B}-p^{*}\right)+b(1-\lambda)+\lambda \Lambda
$$

The price that keeps the firm indifferent between the two governance structures is $\lambda R_{A}-$

\footnotetext{
${ }^{22}$ Note that if $K\left(b / \omega-R_{B}\right)<0$ then $p>b / \omega-R_{B}$ and managers will voluntarily choose the status quo regardless of their loyalty or the governance structure. In this (uninteresting) case, governance is irrelevant since the price of resources is too high to make a change to the status quo ever beneficial to either type of managers.

${ }^{23}$ To reach a mutual agreement, it is implicitly assumed that the shareholder and the manager can either negotiate the cash-flow rights $\omega$, or transfer side-payments at the time of negotiations.
} 
$(1-\lambda) R_{B}+(1-\lambda) b$, which is larger than $\lambda R_{A}-(1-\lambda) R_{B}$, the competitive price of resources as given by Proposition 1. Intuitively, since the private benefits are only obtained if the status quo changes, the indifference of the firm between strong and weak governance requires the price of resources to be higher in order to offset the additional private benefits of the manager. Other than this modification, the analysis remains the same, that is, the corporate governance structure is irrelevant with respect to firm value.

Remark. If the irrelevance of governance is measured with respect to shareholder value and managerial private benefits, then the competitive allocation remains socially efficient when managerial private benefits are taken into account for the same reasons as in the baseline model.

\section{Discussion and Empirical Implications}

In our model, the demand for resources by the universe of firms is affected by the managerial freedom a manager enjoys within a firm's governance structure. While strong governance disincentivizes managers to invest and buy resources, weak governance will do the opposite. Total demand for the resources will be affected by the division of the universe of firms between strong and weak governance. Our model shows that the universe of firms will reach an equilibrium in which some firms have weak governance and other strong governance, but all firms will have the same value. A single firm, or a single shareholder, who are price-takers, cannot increase the value of their firm by switching governance from weak to strong or the other way around. The implications of our model's governance irrelevance result are discussed next.

\subsection{Institutional Investors and Common Ownership}

The irrelevance result does not hold when a shareholder has market power in the ownership of multiple firms. A powerful shareholder with common ownership can affect the division of the universe of firms between weak and strong governance away from the socially efficient equilibrium point. It may have incentives to do so in order to maximize value of its portfolio at the expense of other segments in the economy (such as the labor market). Arguably, BlackRock, Vanguard, and State Street, who hold a portfolio of the capital market, such as index funds, 
might have the power and incentives to do so.

Conceptually, these institutional investors face two alternatives. First, switching more firms from strong to weak governance. Such a strategy will increase the demand for resources and their price, as well as the profitability of their suppliers. The remaining weak governance firms will purchase these resources at a high price, thereby achieving a below-normal rate of return while allowing extra profitability to the suppliers. Under such conditions, and in conformity with the common assumption in empirical studies, the portfolio of weak governance firms will underperform the portfolio of strong governance firms. Alternatively, institutional investors can switch more firms - that is, more than the socially efficient equilibrium - from weak to strong governance. Such a strategy will reduce the demand for resources and their price, as well as the profitability of their suppliers. The remaining weak governance firms will be able to purchase these resources at a low price, thereby achieving an above-normal rate of return at the expense of the suppliers. Under such conditions, and contrary to the common assumption in empirical studies, the portfolio of weak governance firms will outperform the portfolio of strong governance firms.

As our model predicts, in practice, institutional investors push more firms toward strong governance among firms in their portfolio, and not the other way around. ${ }^{24}$ Thus, we will focus our analysis on the consequences of this strategy. Interestingly, the market dynamics that follows from this strategy provides insights regarding the relationship between the prevalent common ownership (Poterba et al. 1995) and several important phenomena: the growing wedge between the returns on capital and on employment (De Loecker and Eeckhout 2017; Barkai 2018); the lower level of investments (Furman and Orszag 2015); and the decrease in the number of firms in the public market (Doidge, Georg and Stulz 2016; EY report 2017). Next, we discuss how common ownership might lead to these phenomena, and then we explain the unique features of having common ownership operating as a monopsony.

\footnotetext{
${ }^{24}$ Our model cannot rule out the possibility that institutional investors who push more firms toward having stronger governance are simply making a mistake (such as believing that strong governance always leads to strong firm performance), or reacting to an exogenous shock that shifted the resources market away from its equilibrium point. However, note that our model implies that in the former case the market portfolio of institutional investors will perform worse than before, and in the latter case firms will voluntarily amend their governance structure until reaching an equilibrium, even without the intervention of common owners.
} 


\subsubsection{Empirical Implications}

Capital Markets v. Labor Markets Increasing the number of strong governance firms in the universe of firms will decrease the demand for resources and consequently their prices. One such a resource is employees ${ }^{25}$ and thus, the return on employment in the labor market will decrease. The decrease in the price of resources will lead to increased profitability of the remaining weak governance firms. Since institutional investors hold diversified portfolios encompassing all firms - common ownership - such a strategy will increase the value of institutional investors' portfolios. However, since this policy deviates from the competitive allocation, the extra profits to common ownership will come at the expense of reducing social efficiency. In this case, the extra returns in the capital market are generated at the expense of lower returns in the labor market. This result is supported by now famous empirical studies showing the widening wedge between the returns on capital and labor (Piketty 2014; Autor et al. 2017).

Capital Markets v. Input Markets The decreased demand for resources will affect not just the labor market but also other suppliers, such as firms selling raw materials. However, given that institutional investors hold the market portfolio, there is a high probability that they will also own the suppliers, and thus will internalize the decreased profitability of the suppliers. Essentially, and unlike the case of labor, the low price of these resources will be a transfer from one account on the institutional investors' portfolio to another. Therefore, the push for more strong governance firms will result in lower returns on the market portfolios owned by institutional investors, as well as in net losses to the economy. In this scenario, the attempt to increase returns in the capital market through an increase in the number of strong governance firms must be either the result of a mistaken belief about the effect of strong governance on firm performance ${ }^{26}$ or a correction of an out-of-equilibrium input market in which the price was abnormally high to begin with, perhaps due to an exogenous shock to supply or productivity.

Capital Markets v. Investments The decrease in demand for resources - labor and other inputs - due to institutional investors with common ownership pushing toward more firms hav-

\footnotetext{
${ }^{25}$ Indeed, strong corporate governance is associated with employee layoffs (Atanassov and Kim 2009).

${ }^{26}$ Alternatively, it might be part of a marketing plan attempted to increase investments by poorly informed savers who mistakenly believe that strong governance always increase firm performance. We do not explore this alternative here.
} 
ing strong governance, will have a combined effect of lower investments in the economy. Strong governance firms invest less, and weak governance firms become more profitable on their (fewer) investments. In their attempt to increase the return on their portfolios, institutional investors with common ownership might have led to an economy with a lower level of investments. In this case, the increased returns in the capital market come at the expense of the economy's reduced growth. This result is supported by the empirical finding that common ownership correlates with reduced investment (Gutiérrez and Philippon 2016).

Public Markets v. Private Markets An alternative view of the universe of firms in our model is including both publicly-traded and privately-owned firms. Privately-owned firms might behave like weak governance firms for several possible reasons. First, private equity and venture capital funds insulate their general partners for seven to ten years through weak governance arrangements. Second, in controlled business firms (such as family-owned firms), there is minimal separation between ownership and control. Since the conflict between the manager and the shareholders is small (i.e., high $\omega$ in our model), the governance structure in such firms is irrelevant, as managers will invest in value increasing projects (project A). Third, privately-owned business firms held by private equity or venture capital funds will commonly have shareholders with strong governance (i.e., with power to fire the manager) but with high competence (i.e., $\tau=1$ in our model), and managers with high compensation package or equity stake (i.e., high $\omega$ in our model). As we show in our model, managers in such firms will also invest in value increasing projects (project A). Finally, relative to publicly-traded firms, privately-owned firms, such as Unicorns, are less exposed to hostile takeovers, hedge fund activism, analysts' quarterly pressure, and other limitations on board insulation through dualclass shares and staggered boards, and can be viewed as weak governance firms. Importantly, under either of the above reasons privately-owned firms in our model will invest and change its status quo.

In such a universe, switching too many publicly-traded firms to strong governance will result in a decline in the price of resources and privately-owned firms enjoying greater returns. The abnormal returns in the private market will lead to more firms wishing to stay private or public firms wishing to go private. Such market forces will decrease the number of publicly traded firms and increase the size of the private market, as indeed was documented (Credit Suisse 
report 2017).

Institutional investors who own a portfolio of both public and the private firms will capture the abnormal returns of their private firms, and the value of their portfolio will increase. However, social efficiency will decline. Moreover, since retail investors cannot participate in the abnormal returns in the private market, inequality will increase (Ljungqvist, Persson and Tåg 2016; Gordon 2018). By contrast, for institutional investors who only own public firms, the returns on their portfolio will decrease together with the social efficiency. While their portfolio of public firms will lose value, other investors will enjoy the abnormal returns in the private market.

\subsubsection{Common Ownership as a Monopsony}

The mechanism through which institutional investors are enhancing the value of their portfolio in our model is different from existing claims of anticompetitive effects of common ownership. In our model, institutional investors have no direct effect on the investment policy of any of the portfolio companies. Institutional investors only have an indirect effect through the right to fire the manager. Importantly, the credible threat to fire managers is not related to the fact that managers contributed (as a collective) to higher prices of resources, but rather, it is related to the inference about managers loyalty from the type of projects they pursue (i.e., project A versus project B). For example, if BlackRock is convinced that a manager chose project $\mathrm{A}$, it would not fire the manager even though this investment contributed to a higher price of resources. In other words, BlackRock in our model does not fire managers because they compete with each other, nor can it commit to doing so. BlackRock only fires managers who reveal by their choices that they are disloyal, and firing such managers is in the best interests of all firm's shareholders regardless of the composition of their portfolios.

The underlying mechanism in our model is also immune to a criticism by Gilje, Gormley and Levit (2018), who point out that due to the very large number of firms in institutional investors' portfolios, they may not be able to pay close attention to all of their portfolio companies, especially not to nuances such as potential externalities between firms. The limited attention in our model could be captured by a lower competence of a highly diversified investor (i.e., a smaller $\tau$, signal's precision). Our results hold as long as shareholders have some information, even if it is arbitrarily small (i.e., $\tau>0.5$ ). Importantly, when exercising their control rights, 
shareholders in our model need not pay attention to decisions made by peer companies or how a decision of their own firm affects its peers; they only need to focus on whether or not they should fire the manager, and the only relevant information for this decision is the business strategy of the firm. Even if one takes the view that diversified investors are completely uninformed (i.e., $\tau=0.5$ ), since in our model there is no conflict between a diversified investor such as BlackRock, and a concentrated investor such as an activist hedge fund, the former can rely on the latter to monitor firms and trigger management replacement if needed (Gilson and Gordon 2013).

Importantly, in our model common ownership creates a monopsony power, not a monopolistic power. Unlike the studies analyzing common ownership as promoting firms' monopoly power (Elhauge 2015; Azar, Schmalz and Tecu 2018), our model is also not vulnerable to criticism regarding the mechanisms through which common ownership promotes tacit collusion or coordination (Hemphill and Kahan 2018). In our model, the manager of each firm maximizes her own value given her rational expectations about the market price of resources and the likelihood of being fired by the firm's shareholders. There is no coordination or collusion, explicit or implicit, between managers of different firms.

Taking together, our model suggests new directions for corporate governance research and its effects on the universe of firms and suppliers, as well as the effects of common ownership.

\subsection{Empirical Studies}

A central theme of corporate governance theory is that governance structure is relevant due to the need of principals to remove disloyal agents, thereby minimizing agency costs. However, our model shows that this justification for governance relevance is insufficient: even when agents vary in their integrity, corporate governance is irrelevant in equilibrium. Therefore, the common hypothesis - that weak governance leads to weak performance - used in many empirical studies is also insufficient.

Take for instance the studies of corporate governance indices (Gompers, Ishii and Metrick 2003; Bebchuk, Cohen and Ferrell 2009). A governance index measures the allocation of control rights between shareholders and managers and rank them along a spectrum from weak (more rights to managers) to strong (more rights to shareholders), and then test for a correlation with firm performance. The hypothesis being that the index will predict firm performance: weak 
governance will correlate with weak performance and strong governance with strong performance. However, as the model shows, although the universe of firms will split between weak and strong governance, in equilibrium, no difference in firm performance should be expected. Moreover, in a market out-of-equilibrium, weak governance firms might either outperform or underperform strong governance firms depending on the direction of the deviation from the equilibrium. Thus, to predict firm performance a governance index must specify which of our model's assumptions do not hold, and the reasons for assuming the market is out-of-equilibrium in a specific direction. Indeed, absent such specifications, the predictive power and validity of governance indices were strongly challenged (Core, Guay and Rusticus 2006; Cremers, Nair and John 2009; Johnson, Moorman and Sorescu 2009).

More generally, the lack of specifications can explain the inconclusive results of the empirical studies. Here are a few commonly absent specifications in the design of empirical studies of corporate governance.

\subsubsection{Market Competitiveness}

When markets are in equilibrium governance is irrelevant. Thus, it is important to ask whether markets for resources are out-of-equilibrium and in what direction. If the supply of resources is abundant and therefore their price is too low, all firms will wish to choose weak governance to induce managers to buy these resources. In such a case, governance is relevant as weak governance outperforms strong governance. On the other hand, when the supply of resources is highly scarce, all firms will wish to switch to strong governance to avoid the excessive price of these resources. In such a case, governance is relevant as strong governance outperforms weak governance.

\subsubsection{Market Power of Firms}

Without market power no firm can improve its value by switching from weak to strong governance or vice versa. Thus, it is important to ask whether firms have market power in the resources' markets. When firms have market power, the equilibrium may not imply governance irrelevance. Firms with market power imply high demand for resources that will move prices up, thereby reducing the return to weak governance firms. Thus, strong governance firms with market power will not switch to weak governance. In equilibrium, firms with weak governance 
will have higher returns than firms with strong governance, but a switch to weak governance will generate negative returns to shareholders of the switching firms due to their market power.

\subsubsection{Shareholders and Managers Characteristics}

As the model shows, several characteristics of shareholders and managers are important for the irrelevance result. Do shareholders have perfect competence? If they do, they will prefer strong governance, as strong governance will generate abnormal returns to shareholders. Do shareholders have market power in the ownership of firms? If they do, they can affect the division of weak and strong governance firms to be out of the socially efficient equilibrium. This is indeed the case of common ownership analyzed above. Do managers have meaningful career concerns? If managers have weak career concerns, then shareholders will prefer strong governance, because strong governance will generate abnormal returns to shareholders. Do managers have sufficient conflict? If they do not, then governance is irrelevant regardless of the other factors.

In sum, empirical studies of corporate governance need to specify these issues to be able to provide more accurate and conclusive results.

\section{Concluding Remarks}

The central theme in the theory of corporate governance is that control rights are necessary to hold disloyal managers accountable and thereby minimize agency costs. Empowering shareholders - i.e., allocating more control rights to shareholders - will, therefore, reduce management agency costs. Many empirical studies adopted, therefore, the prediction that a weak governance structure -i.e., allocation of more control rights to managers - will be associated with weak firm performance due to a high level of agency costs. Our model shows, however, that the relationship between the allocation of control rights and firm performance is more complex than just holding conflicted managers accountable. We show that in a competitive equilibrium, which is socially efficient, when firms do not have market power in the resources market, shareholders do not have perfect competence or market power in the ownership of firms, and managers have meaningful career concerns, the governance structure is irrelevant. 


\section{References}

[1] Acharya, Viral V., Marc Gabarro, and Paolo F. Volpin, 2013, Competition for managers, corporate governance and incentive compensation, Working paper, New York University.

[2] Acharya, Viral V., and Paolo F. Volpin, 2010, Corporate governance externalities, Review of Finance 14, 1-33.

[3] Adams, R. B., and D. Ferreira, 2007, A theory of friendly boards, Journal of Finance 62, 217-250.

[4] Adams, Renée \& Daniel Ferreira, One Share-One Vote: The Empirical Evidence, 12 Rev. Fin. 51-91 (2008)

[5] Adams, Renée B. \& João A.C. Santos, Identifying the Effect of Managerial Control on Firm Performance, 41 J. Acct. \& Econ. 55-85 (2006)

[6] Admati, A. R., P. Pfleiderer, and J. Zechner. 1994. Large shareholder activism, risk sharing, and financial market equilibrium. Journal of Political Economy 102:1097-130.

[7] Aghion, P., and J. Tirole, 1997, Formal and real authority in organizations, Journal of Political Economy 105: 1-29.

[8] Atanassov, Julian and E. Han Kim, Labor And Corporate Governance: International Evidence From Restructuring Decisions, 64 J. Finance, 341-374 (2009)

[9] Autor, David, David Dorn, Lawrence F. Katz, Christina Patterson and John Van Reenen, The Fall of the Labor Share and the Rise of Superstar Firms, NBER Working Paper No. 23396 Issued in (2017)

[10] Azar, José, 2017, Portfolio Diversification, Market Power, and the Theory of the Firm, working paper.

[11] Azar, José, Martin C. Schmalz and Isabel Tecu, Anticompetitive Effects of Common Ownership, 73 J. Finance 1513-1565 (2018)

[12] Barkai Simcha (2018); Declining labor and capital shares. Working Paper.

[13] Bates, Thomas W., David A. Becher \& Michael L. Lemmon, Board Classification and Managerial Entrenchment: Evidence from the Market for Corporate Control, 87 J. Fin. Econ. 656-677 (2008)

[14] Bebchuk, Lucian A. \& Alma Cohen, The Costs of Entrenched Boards, 78 J. Fin. Econ. 409, 419-433 (2005). 
[15] Bebchuk, Lucian A., Alma Cohen \& Allen Ferrell, What Matters in Corporate Governance?, 22 Rev. Fin. Stud. 783-827 (2009)

[16] Bebchuk, Lucian A., Scott Hirst \& June Rhee, Towards the Declassification of S\&P 500 Boards, 3 Harv. Bus. L. Rev. 157-184 (2013)

[17] Brav, Alon, Wei Jiang, Frank Partnoy and Randall Thomas, Hedge Fund Activism, Corporate Governance, and Firm Performance, 63 J. Finance 1729-1775 (2008).

[18] Burkart, M., D. Gromb, and F. Panunzi, 1997, Large shareholders, monitoring, and the value of the firm, The Quarterly Journal of Economics 112 (3), 693-728.

[19] Burkart, Michael, and Konrad Raff, 2014, Performance pay, CEO dismissal and the dual role of takeovers, Review of Finance, forthcoming.

[20] Carleton, Willard T., James M. Nelson, Michael S. Weisbach, The Influence of Institutions on Corporate Governance through Private Negotiations: Evidence from TIAA-CREF, 53 J. Fin. 1335-1362 (1998)

[21] Catan, Emiliano M. \& Marcel Kahan, The Law and Finance of Antitakeover Statutes, 68 Stan. L. Rev. 629-682 (2016);

[22] Chakraborty, A., and B. Yilmaz, 2017, Authority, consensus and governance." Review of Financial Studies 30, 4267-4316.

[23] Cheng, Ing-Haw, 2011, Corporate governance spillovers, Working paper, Dartmouth College.

[24] Comment, Robert and G.William Schwert, Poison Or Placebo? Evidence on The Deterrence and Wealth Effects of Modern Antitakeover Measures, 39 J. Fin. Econ. 3-43 (1995).

[25] Core, John E., Wayne R. Guay and Tjomme O. Rusticus, Does Weak Governance Cause Weak Stock Returns? An Examination of Firm Operating Performance and Investors' Expectations, 61 J. Fin. 655-687 (2006)

[26] Cremers, K.J. Martijn, Saura Masconale \& Simone M. Sepe, Commitment and Entrenchment in Corporate Governance, 110 Nw. U. L. Rev. 727-810 (2016).

[27] Cremers, K.J. Martijn, Vinay B. Nair \& Kose John, Takeovers and the Cross-Section of Returns, 22 Rev. Fin. Stud. 1409-1445 (2009)

[28] deHaan, Ed, David F. Larcker and Charles McClure, Long-Term Economic Consequences of Hedge Fund Activist Interventions (December 31, 2018). Available at SSRN: https://ssrn.com/abstract=3260095 
[29] De Loecker, Jan and Jan Eeckhout, The Rise of Market Power and the Macroeconomic Implications, NBER Working Paper No. 23687 (August 2017).

[30] Demsetz, Harold \& Belén Villalonga, Ownership Structure and Corporate Performance, 7 J. Corp. Fin. 209-233 (2001).

[31] Demsetz, Harold \& Kenneth Lehn, The Structure of Corporate Ownership: Causes and Consequences, 93 J. Pol. Econ. 1155-1177 (1985).

[32] Dicks, David L., 2012, Executive compensation and the role for corporate governance regulation, Review of Financial Studies 25, 1971-2004.

[33] Doidge, Craig, G. Andrew Karolyi and Rene M. Stulz, The U.S. Listing Gap, 123 J. Financial Economics 464-487 (2017)

[34] Edmans, A., D. Levit, and D. Reilly. (2018). Governance Under Common Ownership, Review of Financial Studies, Forthcoming

[35] Elhauge, Einer, Horizontal shareholding, 129 Harv. L. Rev. 1267-1317 (2015)

[36] EY report (May 2017). Looking Behind The Declining Number Of Public Companies An Analysis Of Trends In US Capital Markets, https://www.ey.com/Publication/vwLUAssets/an-analysis-of-trends-in-the-us-capitalmarkets/\$FILE/ey-an-analysis-of-trends-in-the-us-capital-markets.pdf

[37] Friedman, Abe M. et al., S\&P and FTSE Russell on Exclusion of Companies with Multi-Class Shares, Harv. L. School Forum on Corp. Governance and Fin. Reg. (Aug. 5, 2017) https://corpgov.law.harvard.edu/2017/08/05/sp-and-ftse-russell-on-exclusion-ofcompanies-with-multi-class-shares/

[38] Furman, Jason and Peter Orszag, A Firm-Level Perspective on the Role of Rents in the Rise in Inequality (2015) Presentation at "A Just Society" Centennial Event in Honor of Joseph Stiglitz Columbia University

[39] Gilje, Erik, Todd A. Gormley and Doron Levit, Who's Paying Attention? Measuring Common Ownership and Its Impact on Managerial Incentives (2018). Working paper.

[40] Gilson, Ronald J. and Jeffrey N. Gordon, The Agency Costs Of Agency Capitalism: Activist Investors And The Revaluation Of Governance Rights 113 Columbia Law Review 863-927 (2013).

[41] Gompers, Paul, Joy Ishii \& Andrew Metrick, Corporate Governance and Equity Prices, 118 Q.J. Econ. 107-156 (2003). 
[42] Gompers, Paul A., Joy Ishii \& Andrew Metrick, Extreme Governance: An Analysis of Dual-Class Firms in the United States, 23 Rev. Fin. Stud. 1051-1088 (2010)

[43] Gordon, Jeffrey N., Is Corporate Governance A First-Order Cause Of The Current Malaise? 6 J. British Academy, 405-436. (2018).

[44] Goshen, Zohar and Richard Squire, Principal Costs: A New Theory for Corporate Law and Governance 117 Columbia L. Rev. 767-829 (2017).

[45] Grossman, S. J., and O. Hart, 1986, The costs and benefits of ownership: A theory of vertical and lateral integration, Journal of Political Economy 94, 691-719.

[46] Grossman, S. D. and M. Perry (1986): "Perfect Sequential Equilibria." Journal of Economic Theory 39, 97-119.

[47] Gutiérrez, Germán and Thomas Philippon, Investment-less Growth: An Empirical Investigation NBER Working Paper No. 22897 (2016)

[48] Hansen, R.G., Lott Jr., J.R., 1996. Externalities and corporate objectives in a world with diversified shareholder/consumers. Journal of Financial and Quantitative Analysis 31, 4368.

[49] Harris, M., and A. Raviv, 2008, A theory of board control and size, Review of Financial Studies, 21, 1797-1832.

[50] Harris, M., and A. Raviv, 2010, Control of corporate decisions: Shareholders vs. management, Review of Financial Studies 23:4115-47.

[51] Hart, O., and J. Moore. 1990, Property rights and the nature of the firm, Journal of Political Economy 98, 1119-58.

[52] Hemphill, C. Scott and Marcel Kahan, The Strategies of Anticompetitive Common Ownership (2018) https://papers.ssrn.com/sol3/Papers.cfm?abstract_id=3210373

[53] Hermalin, Benjamin E., and Michael S. Weisbach, 1998, Endogenously chosen boards of directors and their monitoring of the CEO, American Economic Review 88, 96-118.

[54] Himmelberg, Charles P., R. Glenn Hubbard \& Darius Palia, Understanding the Determinants of Managerial Ownership and the Link Between Ownership and Performance, 53 J. Fin. Econ. 353-384 (1999)

[55] Holderness, Clifford G., Randall S. Kroszner \& Dennis P. Sheehan, Were the Good Old Days that Good? Changes in Managerial Stock Ownership Since the Great Depression, 54 J. Fin. 435-469 (1999) 
[56] Holmstrom, Bengt, 1999, Managerial incentive problems: A dynamic perspective, Review of Economic Studies 66, 169-182.

[57] Johnson, Shane A., Theodore C. Moorman \& Sorin Sorescu, A Reexamination of Corporate Governance and Equity Prices, 22 Rev. Fin. Stud. 4753-4786 (2009)

[58] Kraus Alan, and Amir Rubin, (2010) "Reducing managers' incentives to cannibalize: Managerial stock options when shareholders are diversified", Journal of Financial Intermediation 19, 439-60.

[59] Lehn, Kenneth, Jeffry Netter \& Annette Poulsen, Consolidating Corporate Control: DualClass Recapitalizations Versus Leveraged Buyouts, 27 J. Fin. Econ. 557, 557 (1990)

[60] Levit, Doron, (2018) "Words Speak Louder Without Actions" Journal of Finance, Forthcoming

[61] Levit Doron, Nadya Malenko The Labor Market for Directors and Externalities in Corporate Governance, Journal of Finance, 71(2), 775-808, April 2016

[62] Ljungqvist, Alexander, Lars Persson and Joacim Tåg, Private Equity's Unintended Dark Side: On the Economic Consequences of Excessive Delistings NBER Working Paper No. 21909 (2016)

[63] López, A. L., and X. Vives (forthcoming): "Overlapping Ownership, R\&D Spillovers and Antitrust Policy," Journal of Political Economy.

[64] Masulis, Ronald W., Cong Wang \& Fei Xie, Agency Problems at Dual-Class Companies, 64 J. Fin. 1697-1727 (2009)

[65] Credit Suisse. The Incredible Shrinking Universe of Stocks: The Causes and Consequences of Fewer U.S. Equities, Credit Suisse (2017) https://www.cmgwealth.com/wpcontent/uploads/2017/03/document_1072753661.pdf

[66] McCahery, J., A. Sautner, and L. T. Starks, 2016, Behind the scenes: The corporate governance preferences of institutional investors, Journal of Finance 71, 2905-2932.

[67] McConnell, John J. \& Henri Servaes, Additional Evidence on Equity Ownership and Corporate Value, 27 J. Fin. Econ. 595-612 (1990)

[68] Morck, Randall, Andrei Shleifer \& Robert W. Vishny, Management Ownership and Market Valuation, 20 J. Fin. Econ. 293-315 (1988)

[69] Nielsen, Anders E. B., 2006, Evolution of corporate governance, externalities and multiple equilibria, Working paper, Princeton University. 
[70] NYSE petition - Council of Institutional Investors, October 24, 2018. https://www.cii.org/files/issues_and_advocacy/correspondence/FINAL\%20Dual\%20Class\%20Petiti

[71] O'Brien, D. P., and S. C. Salop (2000): Competitive effects of partial ownership: Financial interest and corporate control," Antitrust Law Journal, pp. 559-614.

[72] Partch, M. Megan, The Creation of a Class of Limited Voting Common Stock and Shareholder Wealth, 18 J. Fin. Econ. 313-339 (1987)

[73] Piketty, Thomas (2014) Capital in the 21st Century. Cambridge, MA: Belknap Press.

[74] Poterba, James M. et al., Stock Ownership Patterns, Stock Market Fluctuations, and Consumption, Brookings Papers on Econ. Activity 295-372 (1995)

[75] Rubin, A., 2006. Diversification and corporate decisions. Corporate Ownership and Control $3,209-212$.

[76] Ryngaert, Michael, The Effect of Poison Pill Securities on Shareholder Wealth, 20 J. Fin. Econ. 377-417 (1988)

[77] Smart, Scott B., Ramabhadran S.Thirumalai and Chad J.Zutter, What's In A Vote? The Short-And Long-Run Impact Of Dual-Class Equity On IPO Firm Values, 45 J. Accounting and Economics, 94-115 (2008),

[78] Smith, Michael P., Shareholder Activism by Institutional Investors: Evidence from CalPERS, 51 J. Fin. 227-252 (1996).

[79] Stein, Jeremy C., Takeover Threats and Managerial Myopia, 96 J. Pol. Econ. 61 (1988).

[80] Stein, Jeremy C., Efficient Capital Markets, Inefficient Firms: A Model of Myopic Corporate Behavior, 104 Q.J. Econ. 655 (1989).

[81] Straska, Miroslava \& H. Gregory Waller, Antitakeover Provisions and Shareholder Wealth: A Survey of the Literature, 49 J. Fin. \& Quantitative Analysis 933-956 (2014)

[82] Subramanian, Guhan, Delaware's Choice, 39 Del. J. Corp. L. 1-54 (2014)

[83] Zwiebel, Jeffrey, 1995, Corporate conservatism and relative compensation, Journal of Political Economy 103, 1-25. 


\section{A Proofs of Main Results}

We start with two auxiliary lemmas that are used in the proofs of Lemmas 1 and 2 . The proofs of all auxiliary results are in Appendix B.

Lemma 3 In any equilibrium in which the manager keeps the status quo on the path, the manager is not fired by the shareholder upon doing so.

Lemma 4 In any equilibrium, the disloyal manager never chooses project $A$ and the loyal manager never chooses project $B$.

Proof of Lemma 1. Based on Lemma 4, the disloyal manager never chooses project A and the loyal manager never chooses project B in equilibrium. Therefore, without the risk of being fired, the loyal manager prefers $x_{i}=A$ over $x_{i}=0$ if and only if $R_{A} \geq p$, and the disloyal manager prefers $x_{i}=B$ over $x_{i}=0$ if and only if $b / \omega-R_{B} \geq p$. The statement in the lemma follows from these observations.

Proof of Lemma 2. Suppose $c_{i}=S H$. Based on Lemma 4, there are two cases to consider: 1. First, suppose in equilibrium the loyal manager chooses $x_{i}=0$. We argue the disloyal manager also chooses $x_{i}=0$. To see why, note that according to Lemma 3, the shareholder does not fire the manager upon $x_{i}=0$ in such equilibrium. Moreover, if on the contrary the disloyal manager chooses $x_{i} \neq 0$, then upon $x_{i} \neq 0$ the shareholder must infer that the manager is disloyal, and as a result, he has incentive to fire him irrespective of the realization of signal $s$. However, $\Gamma>\Gamma^{*}$ implies $b+\omega\left(v-R_{B}-p\right)<\omega v+\Gamma$, and therefore the disloyal manager is better off choosing $x_{i}=0$ over project $\mathrm{B}$ (and project $\mathrm{A}$, as $b / \omega>R_{A}+R_{B}$ ), a contradiction. Therefore, the manager chooses $x_{i}=0$ regardless of his loyalty.

2. Second, suppose in equilibrium the loyal manager chooses $x_{i}=A$. Based on Lemma 4, the disloyal manager either chooses $x_{i}=0$ or $x_{i}=B$. In the former case, $x_{i}=0$ reveals the manager is disloyal, and $x_{i} \neq 0$ reveals the manager is loyal. Therefore, the shareholder fires the manager upon observing $x_{i}=0$, and does not fire him, regardless of the realization of signal $s$, upon observing $x_{i} \neq 0$. However, this contradicts Lemma 3. We conclude, the disloyal manager chooses project $\mathrm{B}$ in this case, and $x_{i}=0$ is off-equilibrium.

The arguments above suggest that there could be only two types of equilibrium (at the firm level) when $c_{i}=S H$. We argue that the equilibrium is as described by part 1 above. 
To see why, suppose to the contrary that the equilibrium is as described by part 2 . The shareholder has incentive to fire the manager if and only if he observes signal $s=B$. This implies that the equilibrium payoff of the loyal manager is $\omega\left(v+R_{A}-p\right)+\tau \Gamma$, and the equilibrium payoff of the disloyal manager is $b+\omega\left(v-R_{B}-p\right)+(1-\tau) \Gamma$. Notice that the assumption $\Gamma>\Gamma^{*}$ implies $\frac{\omega\left(R_{A}-p\right)}{1-\tau}<\Gamma$, and hence, the loyal manager prefers deviating to $x_{i}=0$ if upon such deviation the shareholder does not fire him. If in addition $\frac{b-\omega\left(R_{B}+p\right)}{\tau}<\Gamma$, then $b+\omega\left(v-R_{B}-p\right)+(1-\tau) \Gamma<\omega v+\Gamma$ and conditional upon not being fired when choosing $x_{i}=0$, both the loyal and the disloyal manage prefer such deviation, and upon such deviation, the shareholder will find it optimal not to fire the manager (since the replacement manager has the same probability of being loyal). In this case the equilibrium described by part 2 does not survive the Grossman and Perry (1986) criterion. If instead $\frac{b-\omega\left(R_{B}+p\right)}{\tau} \geq \Gamma$, then $b+\omega\left(v-R_{B}-p\right)+(1-\tau) \Gamma>\omega v+\Gamma$ and conditional upon not being fired when choosing $x_{i}=0$ only the loyal manager prefers such deviation, and upon such deviation, the shareholder will indeed find it optimal not to fire the manager. Therefore, in this case as well the equilibrium described by part 2 does not survive the Grossman and Perry (1986) criterion. We conclude that the equilibrium must be as described by part 1 .

Finally, we prove that the equilibrium described by part 1 (in which the manager choose $x_{i}=0$ irrespective of his type) survives the Grossman and Perry (1986) criterion. Suppose that off the equilibrium path, when $x_{i} \neq 0$, the shareholder fires the manager regardless of the realization of signal $s$. Note that under the equilibrium pay, the manager obtains $\omega v+\Gamma$ regardless of his type. The assumption $\Gamma>\Gamma^{*}$ guarantees that for any admissible price $p$, a deviation of either type to $x_{i} \neq 0$ is not profitable if they are expected to be fired. We show that these off-equilibrium beliefs are indeed credible. We consider three cases:

1. First, consider a deviation to $x_{i} \neq 0$ only by the disloyal manager. Then, upon such deviation, the shareholder knows that the manager is disloyal, and therefore, he has strict incentives to fire the manager. However, the assumptions $\Gamma>\Gamma^{*}$ and $p \geq \underline{p}$ imply that the manager's payoff under this deviation is strictly smaller than $\omega v+\Gamma$. So such deviation is not feasible.

2. Second, consider a deviation to $x_{i} \neq 0$ only by the loyal manager. Then, upon such deviation, the shareholder does not fire the manager with a positive probability. Since $\tau<1$, it must be that the shareholder ignores the realization of signal $s$. However, if the loyal manager finds a deviation to $x_{i}=A$ beneficial relative to $x_{i}=0, b / \omega-R_{B}>R_{A}$ implies that a disloyal 
manager also finds a deviation to $x_{i}=B$ beneficial relative to $x_{i}=0$. So such deviation is not feasible.

3. Third, consider a deviation to $x_{i} \neq 0$ that includes both types. For the reasons that are behind Lemma 4, if such deviation exists, it must be that the loyal manager chooses project A and the disloyal manager chooses project B. But upon such deviation the shareholder fires the manager if and only if $s=B$. The assumptions $\Gamma>\Gamma^{*}$ and $p>p$ imply that the loyal manager's payoff under the equilibrium play will be higher. So this deviation is not feasible either.

Combined, the three cases above establish that when $c_{i}=S H$, an equilibrium in which all types of managers choose $x_{i}=0$ survives the Grossman and Perry (1986) criterion, and therefore, it exists.

Proof of Proposition 1. We start by proving that in any equilibrium there are firms $i \neq j$ such that $c_{i}^{*}=M$ and $c_{j}^{*}=S H$. Suppose to the contrary that in equilibrium all shareholders choose the same $c^{*} \in\{M, S H\}$. In equilibrium, the market must clear. Therefore, exactly $K(p)$ firms must change the status quo and $N-K(p)$ firms must keep it. Two cases must be considered:

1. First, suppose $c^{*}=S H$. According to Lemma 2, all managers keep the status quo in equilibrium. Therefore, this equilibrium requires $K\left(p^{*}\right)=0$, which implies $p^{*}=p$. The expected shareholder value in equilibrium is $(1-\omega) v+\lambda \Lambda$. Consider a deviation of shareholder $i$ to $c_{i}=M$. Recall the assumption $0<K\left(\lambda R_{A}-(1-\lambda) R_{B}\right)$, which implies, $\underline{p}<\lambda R_{A}-$ $(1-\lambda) R_{B}$. Also note that $\lambda R_{A}-(1-\lambda) R_{B}<R_{A}<b / \omega-R_{B}$. Therefore, $\underline{p}<R_{A}<b / \omega-R_{B}$. According to Lemma 1, the manager of firm $i$ chooses project $\mathrm{A}$ if he is loyal and chooses project $\mathrm{B}$ if he is disloyal. Notice that the equilibrium implied by $c_{i}=M$ survives the Grossman and Perry (1986) criterion since no type of manager can obtain a higher payoff by changing his strategy, no matter what the shareholders beliefs are. Under this deviation, the expected shareholder value is $(1-\omega)\left[v+\lambda\left(R_{A}-\underline{p}\right)-(1-\lambda)\left(R_{B}+\underline{p}\right)\right]+\lambda \Lambda$, which is strictly greater than $(1-\omega) v+\lambda \Lambda$ as long as $\underline{p}<\lambda R_{A}-(1-\lambda) R_{B}$, which holds. Therefore, we get a contradiction.

2. Second, suppose $c^{*}=M$. Three subcases must be considered:

(a) If $p^{*}>b / \omega-R_{B}$ then according to Lemma 1, the manager chooses $x_{i}=0$ regardless of 
his loyalty. This equilibrium requires $K\left(p^{*}\right)=0 \Rightarrow p^{*}=\underline{p}$, which implies $\underline{p}>b / \omega-R_{B}$. However, recall the assumption $\underline{p}<\lambda R_{A}-(1-\lambda) R_{B}$. Since $\lambda R_{A}-(1-\lambda) R_{B}<R_{A}<$ $b / \omega-R_{B}$, we get a contradiction.

(b) If $R_{A}<p^{*} \leq b / \omega-R_{B}$ then according to Lemma 1 , the loyal manager chooses $x_{i}=$ 0 and disloyal manager chooses $x_{i}=B$. The expected payoff of the shareholder in this equilibrium is $(1-\omega)\left(v-(1-\lambda)\left(R_{B}+p^{*}\right)\right)+\lambda \Lambda$. Consider a deviation of the shareholder $i$ to $c_{i}=S H$. According to Lemma 2, the manager must be choosing $x_{i}=0$ regardless of his type, and this equilibrium survives the Grossman and Perry (1986) criterion. Since under this equilibrium the shareholder expected payoff is $(1-\omega) v+\lambda \Lambda$, which is strictly higher than the equilibrium payoff, the deviation of the shareholder to $c_{i}=S H$ is strictly optimal, yielding a contradiction.

(c) If $p^{*} \leq R_{A}$ then, according to Lemma $1, c_{i}^{*}=M$ implies that in equilibrium the manager chooses $x_{i} \neq 0$ regardless of his loyalty. Therefore, $N$ firms change the status quo and the market clears only if $K\left(p^{*}\right)=N$. The expected shareholder value in this equilibrium is

$$
(1-\omega)\left[v+\lambda\left(R_{A}-p^{*}\right)-(1-\lambda)\left(R_{B}+p^{*}\right)\right]+\lambda \Lambda .
$$

Consider a deviation of shareholder $i$ to $c_{i}=S H$. According to Lemma 2, the manager chooses $x_{i}=0$ regardless of his type upon such deviation, and the expected shareholder payoff is $(1-\omega) v+\lambda \Lambda$. Therefore, a deviation to $c_{i}=S H$ is not profitable if and only if $p^{*} \leq \lambda R_{A}-(1-\lambda) R_{B}$. However, the market clearing condition requires $K\left(p^{*}\right)=N$, which implies $N \leq K\left(\lambda R_{A}-(1-\lambda) R_{B}\right)$. This condition, however, contradicts the assumption $K\left(\lambda R_{A}-(1-\lambda) R_{B}\right)<N$. Therefore, $c_{i}^{*}=M$ for all $i$ cannot be an equilibrium.

We have shown that in any equilibrium there are at least two firms $i \neq j$ such that $c_{i}^{*}=S H$ and $c_{i}^{*}=M$. Since firms are ex-ante identical and have no market power, shareholders must be indifferent between these different choices. According to Lemma 2, if $c_{i}^{*}=S H$ then in equilibrium the manager chooses $x_{i}=0$ regardless of his type and the shareholder does not fire him. Therefore, the expected shareholder value in those firms is $(1-\omega) v+\lambda \Lambda$. Since shareholders are indifferent, the expected shareholder value when $c_{i}^{*}=M$ must also be $(1-\omega) v+\lambda \Lambda$. Consider firms with $c_{i}^{*}=M$, and note that there are three cases to consider, depending on the 
price of resources:

1. First, if $p^{*}>b / \omega-R_{B}$ then according to Lemma 1 , the manager chooses $x_{i}=0$ regardless of his loyalty. This equilibrium requires $K\left(p^{*}\right)=0 \Rightarrow p^{*}=p$, which implies $p>b / \omega-R_{B}$. However, recall the assumption $\underline{p}<\lambda R_{A}-(1-\lambda) R_{B}$. Since $\lambda R_{A}-(1-\lambda) R_{B}<R_{A}<$ $b / \omega-R_{B}$, we get a contradiction.

2. Second, if $R_{A}<p^{*}<b / \omega-R_{B}$ then according to Lemma 1, the manager chooses $x_{i}=$ 0 if and only if he is loyal. The expected payoff of the shareholder in this equilibrium is $(1-\omega)\left(v-(1-\lambda)\left(R_{B}+p^{*}\right)\right)+\lambda \Lambda$, which is smaller than $(1-\omega) v+\lambda \Lambda$ as long as $R_{B}+p^{*}>0$, which holds since $p^{*}>R_{A}$. Therefore, the shareholder cannot be indifferent, a contradiction.

3. Third, therefore, it must be $p^{*} \leq R_{A}$. In this case, the loyal manager chooses $x_{i}=A$, and the disloyal manager chooses $x_{i}=B$. The expected shareholder value is

$$
(1-\omega)\left[v+\lambda\left(R_{A}-p^{*}\right)-(1-\lambda)\left(R_{B}+p^{*}\right)\right]+\lambda \Lambda
$$

Shareholders are indifferent between $c_{i}=S H$ and $c_{i}=M$ if and only if $p^{*}=\lambda R_{A}-(1-\lambda) R_{B}$. The market clears at this price if and only if exactly $K\left(\lambda R_{A}-(1-\lambda) R_{B}\right)$ firms change the status quo, which implies that $K\left(\lambda R_{A}-(1-\lambda) R_{B}\right)$ firms choose $c_{i}^{*}=M$, as required. Assumption (2) guarantees $K\left(\lambda R_{A}-(1-\lambda) R_{B}\right) \in(0, N)$.

The next auxiliary result, which establishes the equilibrium when the number of firms with weak governance is exogenous, is used in the proof of propositions 2 and 3.

Lemma 5 Suppose the number of firms with weak governance is exogenously given by $n \in$ $[0, N]$, and let the corresponding price of resources in equilibrium be $p(n)$. Then

$$
p(n)= \begin{cases}K^{-1}(n) & \text { if } n \leq K\left(R_{A}\right) \\ R_{A} & \text { if } K\left(R_{A}\right)<n \leq \frac{1}{1-\lambda} K\left(R_{A}\right) \\ K^{-1}(n(1-\lambda)) & \text { if } \frac{1}{1-\lambda} K\left(R_{A}\right)<n<\frac{1}{1-\lambda} K\left(b / \omega-R_{B}\right) \\ b / \omega-R_{B} & \text { if } \frac{1}{1-\lambda} K\left(b / \omega-R_{B}\right) \leq n .\end{cases}
$$

(i) The equilibrium behavior of firms with strong governance is as characterized by Lemma 2. 
(ii) The equilibrium behavior of firms with weak governance is:27

(a) If $n \leq K\left(R_{A}\right)$ then the loyal manager chooses project $A$, and the disloyal manager chooses project $B$.

(b) If $K\left(R_{A}\right)<n \leq \frac{1}{1-\lambda} K\left(R_{A}\right)$ then the loyal manager chooses project $A$ with probability $\eta \in(0,1)$ and the status quo with probability $1-\eta$, and the disloyal manager chooses project B. $\eta$ satisfies $(\lambda \eta+1-\lambda) n=K\left(R_{A}\right)$.

(c) If $\frac{1}{1-\lambda} K\left(R_{A}\right)<n \leq \frac{1}{1-\lambda} K\left(b / \omega-R_{B}\right)$ then then the loyal manager keeps the status quo and the disloyal manager chooses project $B$.

(d) If $\frac{1}{1-\lambda} K\left(b / \omega-R_{B}\right)<n$ then then the loyal manager keeps the status quo and the disloyal manager chooses project $B$ with probability $\varphi \in(0,1)$ and the status quo with probability $1-\varphi$, such that $\varphi=\frac{1}{1-\lambda} \frac{K\left(b / \omega-R_{B}\right)}{n}$.

Proof of Proposition 2. Consider an allocation of control rights where the mass of firms with weak governance is $\hat{n}$. Based on Lemma 5 , the corresponding price of resources is $p(\hat{n})$, as given by Expression (13). Recall that according to Proposition 1, the competitive allocation is $n^{*}=K\left(p^{*}\right)$ where $p^{*}=\lambda R_{A}-(1-\lambda) R_{B}$ is the corresponding price of resources. Note that $p^{*}=p\left(n^{*}\right)$. We consider several cases:

1. First, suppose $\hat{n} \in\left[0, n^{*}\right)$. Relative to the competitive allocation, $n^{*}-\hat{n}$ firms with weak governance switched to strong governance. Since $\hat{n}<n^{*}=K\left(\lambda R_{A}-(1-\lambda) R_{B}\right)<K\left(R_{A}\right)$, we have $\hat{n}<K\left(R_{A}\right)$. According to Lemma 5 part ii.a, if $\hat{n}<K\left(R_{A}\right)$ then $p(\hat{n})=K^{-1}(\hat{n})<$ $\lambda R_{A}-(1-\lambda) R_{B}=p\left(n^{*}\right)$. Moreover, in this region firms with strong (weak) governance under allocation $\hat{n}$ behave the same way as firms with strong (weak) governance under allocation $n^{*}$. The only difference between the allocations is that under allocation $\hat{n}$ the price of resources is lower and the number of firms with weak governance is lower. The added total social value that is created by the mass of firms that switched from weak to strong governance is $-\left(n^{*}-\hat{n}\right)\left(\lambda R_{A}-(1-\lambda) R_{B}\right) \cdot{ }^{28}$ At the same time, there is a mass of $n^{*}-\hat{n}$ suppliers who sold their assets under allocation $n^{*}$ but retained them under allocation $\hat{n}$. The valuations of these suppliers span the interval $\left[p(\hat{n}), \lambda R_{A}-(1-\lambda) R_{B}\right]$. Therefore, the total alternative use

\footnotetext{
${ }^{27}$ Notice that we allow for mixed strategies by the manager; doing so will not change our main results in the main text in a material way.

${ }^{28}$ Although the change in price of resources affects all firms, firms that did not change their decisions as a consequence do not affect the allocation of resources, and therefore, do not affect social welfare.
} 
of their assets is smaller than the value that could have been created to the switching firms had they maintained their weak governance and bought these assets. Therefore, any allocation $\hat{n}<n^{*}$ has a lower social value than $W^{*}$.

2. Second, suppose $\hat{n} \in\left(n^{*}, N\right]$. Relative to the competitive allocation, $\hat{n}-n^{*}$ firms with strong governance switched to weak governance. According to Lemma 5 part (i), under the new allocation, the firms that kept their strong governance will maintain the status quo under the new allocation. However, based on Lemma 5 part (ii), the demand of firms with weak governance (of firms which had weak governance under the competitive allocation and of the firms which switched to weak governance under the new allocation) might change depending on the price of resources under the new allocation (notice that Lemma 5 guarantees that an equilibrium exists under allocation $\hat{n}$ ). There are four subcases to consider:

(a) Suppose $p(\hat{n})<R_{A}$. Based on Lemma 5, it must be $\hat{n} \leq K\left(R_{A}\right)$, and based on part (ii.a) of this lemma, the behavior of firms with weak governance is the same as under allocation $n^{*}$. Since there are more firms with weak governance under allocation $\hat{n}$, the demand for resources is higher that under allocation $n^{*}$. Therefore, it must be $\lambda R_{A}-(1-\lambda) R_{B}<$ $p(\hat{n})$. Notice that the added social value that is created by each firm that switched from strong to weak governance is $\lambda R_{A}-(1-\lambda) R_{B}$. At the same time, there is a mass of $\hat{n}-n^{*}$ suppliers who retained their assets under allocation $n^{*}$ but sell them under the new allocation. The valuations of these suppliers span the interval $\left[\lambda R_{A}-(1-\lambda) R_{B}, p(\hat{n})\right]$. Therefore, the alternative use of their assets is higher than the value that is created to the firms that switched to weak governance and bought these assets. As a result, any allocation of control rights that satisfies $\hat{n}>n^{*}$ and $p(\hat{n})<R_{A}$ produces a lower social value than $W^{*}$.

(b) Suppose $p(\hat{n})=R_{A}$. Based on Lemma 5, it must be $K\left(R_{A}\right)<\hat{n} \leq \frac{1}{1-\lambda} K\left(R_{A}\right)$, and based on part (ii.b) of this lemma, under the new allocation the behavior of firms with weak governance is the following: the loyal manager chooses project A with probability $\eta \in(0,1)$ and the status quo with probability $1-\eta$, and the disloyal manager chooses project B. Since every instance in which a firm invests in project A creates social welfare (the firm creates a value of $R_{A}$ where the alternative use of the supplier is smaller than $\left.p(\hat{n})=R_{A}\right)$, the social welfare under this allocation is lower than it would have been had the loyal manager invested in project $\mathrm{A}$ with probability one rather than $\eta$. However, 
for the same reason as in part (a) above, the social welfare that would have been created with $\eta=1$ is lower than the social welfare that is created by the competitive allocation.

(c) Suppose $R_{A}<p(\hat{n})<b / \omega-R_{B}$. Based on Lemma 5, it must be $\frac{1}{1-\lambda} K\left(R_{A}\right)<\hat{n}<$ $\frac{1}{1-\lambda} K\left(b / \omega-R_{B}\right)$, and based on part (ii.c) of this lemma, under the new allocation firms with weak governance change the status quo if and only if the manager is disloyal, and when they do, they choose project B. Since $R_{A}>-R_{B}$, any transaction in which the supplier's alternative use of the asset is in the interval $\left[R_{A}, p(\hat{n})\right]$, and the asset is sold to a firm with weak governance, is socially inefficient. Therefore, an allocation as in part (b) above generates a strictly higher social welfare, as it avoids these transactions. Moreover, in allocations in part (b) project $\mathrm{A}$ is sometimes chosen, which is socially efficient. Recall that the allocation in part (b) is inferior to the competitive allocation $n^{*}$. Therefore, from transitivity, it must be that any allocation that satisfies $\hat{n}>n^{*}$ and $R_{A}<p(\hat{n})<b / \omega-R_{B}$ is also socially inefficient.

(d) Suppose $b / \omega-R_{B} \leq p(\hat{n})$. Based on Lemma 5 , it must be $b / \omega-R_{B}=p(\hat{n})$ and $\frac{1}{1-\lambda} K\left(b / \omega-R_{B}\right) \leq \hat{n}$, and based on part (ii.d) of this lemma, under the new allocation firms with weak governance change the status quo only if the manager is disloyal, and when they do, they choose project B. Therefore, for the same reason as in part (c) above, the social welfare under this allocation is lower than the social welfare that is created by the competitive allocation.

Proof of Proposition 3. Denote the allocation that maximizes total shareholder value by $n_{S H}^{*}$. According to Lemma 5 , if $K\left(R_{A}\right)<n$ then $p(n) \geq R_{A}$, and therefore, any change to the status quo necessarily strictly decreases shareholder value (since project B is chosen with a strictly positive probability). Therefore, it must be $n_{S H}^{*}<K\left(R_{A}\right)$. Moreover, if $n>K\left(\lambda R_{A}-(1-\lambda) R_{B}\right)$, then $p(n)>\lambda R_{A}-(1-\lambda) R_{B}$, which implies that a change to the status quo is a negative NPV. Therefore, it must be $n_{S H}^{*} \leq n^{*}$. We argue that $n_{S H}^{*}<n^{*}$. As argued in the main text, if $n=n^{*}$ then the expected shareholder value in firms with strong and weak governance is $v$. However, if $n<n^{*}$, then the price of resources must be strictly smaller than $\lambda R_{A}-(1-\lambda) R_{B}$, the competitive price, which implies that the expected value that is created for each firm with weak governance is strictly larger than $v$. Therefore, the total shareholder value is strictly larger than $N v$, which implies $n_{S H}^{*}<n^{*}$. Recall from Lemma 5 
that $n<K\left(R_{A}\right)$ implies $p(n)=K^{-1}(n)$. Therefore,

$$
n_{S H}^{*} \in \arg \max _{n \in\left[0, n^{*}\right]} n\left(\lambda\left(R_{A}-K^{-1}(n)\right)-(1-\lambda)\left(R_{B}+K^{-1}(n)\right)\right)
$$

or equivalently, the price that corresponds to the optimal allocation solves

$$
p_{S H}^{*} \in \arg \max _{p \in\left[0, p^{*}\right]} K(p)\left(\lambda\left(R_{A}-p\right)-(1-\lambda)\left(R_{B}+p\right)\right)
$$

\section{B Proofs of Auxiliary Results}

Proof of Lemma 3. If $c_{i}=M$ then the shareholder does not have the right to fire the manager and the result follows trivially. Suppose $c_{i}=S H$, and on the contrary that $x_{i}=0$ is on the equilibrium path but the manager is fired by the shareholder. Then, it must be that the loyal manger chooses $x_{i} \neq 0$. Otherwise, the replacement manager has a weakly lower probability of being loyal than a manager who chooses $x_{i}=0$, and the shareholder would have no incentive to fire the manager upon $x_{i}=0$. Therefore, $x_{i}=0$ is chosen by the disloyal manager. Since $x_{i} \neq 0$ is chosen by the loyal manager, the shareholder does not fire the manager upon $x_{i} \neq 0$ irrespective of the realization of signal $s$. Therefore, the loyal manager must prefer project A over project B. By revealed preferences of the loyal manager, it must be $\omega\left(v+R_{A}-p\right)+\Gamma>\omega v$, which implies that the disloyal manager has a strictly profitable deviation to project $\mathrm{B}$, thereby generating a payoff of $b+\omega\left(v-R_{B}-p\right)+\Gamma$. Since $b / \omega-R_{B}>R_{A}$ and $\omega\left(v+R_{A}-p\right)+\Gamma>\omega v$, this deviation is optimal, a contradiction.

Proof of Lemma 4. Suppose on the contrary the loyal manager chooses $x_{i}=B$ in equilibrium. Then, it must be $c_{i}=S H$ and that the manager is strictly more likely to be fired upon choosing $x_{i}=A$ than upon $x_{i}=B$. Therefore, and since $b / \omega-R_{B}>R_{A}$, a disloyal manager strictly prefers project $B$ over project $A$. In other words, project $A$ is never chosen by the manager on the equilibrium path. If so, and because $\tau<1$, signal $s$ is uninformative about the manager's type and the shareholder will ignore it when deciding whether to fire the manager. That is, from the manager's perspective, the probability of being fired is the same whether he chooses project $\mathrm{A}$ or project $\mathrm{B}$. Therefore, the loyal manager has a strictly profitable deviation 
from $x_{i}=B$ to $x_{i}=A$, a contradiction.

Next, suppose on the contrary the disloyal manager chooses $x_{i}=A$ in equilibrium. By the previous argument, the loyal manager is not choosing $x_{i}=B$ in this equilibrium. Therefore, there are two cases to consider:

1. If the loyal manager chooses $x_{i}=0$, then conditional on $x_{i} \neq 0$ the manager must be disloyal. Therefore, the realization of signal $s$ does not affect the decision of the shareholder to fire the manager; the manager is either fired with probability one or zero upon $x_{i} \neq 0$. Therefore, and since $b / \omega-R_{B}>R_{A}$, the disloyal manager is strictly better off choosing $x_{i}=B$, a contradiction. 2. Suppose the loyal manager chooses $x_{i}=A$. The disloyal manager chooses $x_{i}=A$ as well, only if $c_{i}=S H$ and he expects to be fired with a strictly higher probability upon choosing $x_{i}=B$. However, if the manager chooses project A regardless of his loyalty, signal $s$ is uninformative about the manager loyalty, and the shareholder's decision to fire the manager cannot depend on the realization of signal $s$. If so, and since $b / \omega-R_{B}>R_{A}$, the disloyal manager is strictly better off choosing $x_{i}=B$, a contradiction.

Proof of Lemma 5. First note that according to Lemma 2, the behavior of firms with strong governance does not depend on the price of resources or the total number of firms with strong governance. Therefore, part (i) follows immediately. Part (ii) and the form of $p(n)$ follow from the combination of the five cases below:

1. If $p(n)<R_{A}$ then based on Lemma 1, the behavior of each firm with weak governance will be the same as under the competitive equilibrium described by Proposition 1. Therefore, the demand for resources will be $n$ and market clearing implies $K(p(n))=n$, which requires $n<K\left(R_{A}\right)$.

2. If $p(n)=R_{A}$ then based on Lemma 1, the disloyal manager chooses project $\mathrm{B}$ and the loyal manager is indifferent between project $\mathrm{A}$ and the status quo. Therefore, he can mix between the two choices. Letting $\eta$ be the probability with which he chooses project A, market clearing implies $(\lambda \eta+1-\lambda) n=K\left(R_{A}\right)$, which requires $K\left(R_{A}\right) \leq n \leq \frac{1}{1-\lambda} K\left(R_{A}\right)$.

3. If $R_{A}<p(n)<b / \omega-R_{B}$ then based on Lemma 1 the loyal manager keeps the status quo and the disloyal manager chooses project B. Therefore, the demand for resources will be $n(1-\lambda)$ and market clearing implies $K(p(n))=n(1-\lambda)$, which requires $\frac{1}{1-\lambda} K\left(R_{A}\right)<n<$ $\frac{1}{1-\lambda} K\left(b / \omega-R_{B}\right)$. 
4. If $p(n)=b / \omega-R_{B}$ then based to Lemmas 1 , the loyal manager keeps the status quo and the disloyal manager is indifferent between project $\mathrm{B}$ and the status quo. Therefore, he can mix between the two choices. Letting $\varphi$ be the probability with which he chooses project B, market clearing implies $\varphi(1-\lambda) n=K\left(b / \omega-R_{B}\right)$, which requires $\frac{1}{1-\lambda} K\left(b / \omega-R_{B}\right) \leq n$.

5. If $p(n)>b / \omega-R_{B}$ then based to Lemmas 1 , the manager always keeps the status quo. Therefore, it must be $p(n)=\underline{p}$, which implies $b / \omega-R_{B}<\underline{p}$. However, the assumption $0<K\left(\lambda R_{A}-(1-\lambda) R_{B}\right)$ implies $\underline{p}<\lambda R_{A}-(1-\lambda) R_{B}<R_{A}<b / \omega-R_{B}$. Therefore, this cannot be true in equilibrium.

\section{Proofs of Results in Section 4}

Proposition 4 (Weak managerial career concerns) Suppose $\Gamma=0$. Then, the price of resources in equilibrium is

$$
p(N)= \begin{cases}K^{-1}(N) & \text { if } N<K\left(R_{A}\right) \\ R_{A} & \text { if } K\left(R_{A}\right)<N \leq \frac{1}{1-\lambda} K\left(R_{A}\right) \\ K^{-1}(N(1-\lambda)) & \text { if } \frac{1}{1-\lambda} K\left(R_{A}\right)<N<\frac{1}{1-\lambda} K\left(b / \omega-R_{B}\right) \\ b / \omega-R_{B} & \text { if } \frac{1}{1-\lambda} K\left(b / \omega-R_{B}\right) \leq N,\end{cases}
$$

and all firms adopt strong governance. Moreover:

(i) If $N \leq K\left(R_{A}\right)$ then the loyal manager chooses project $A$ and the disloyal manager chooses project $B$. The shareholder fires the manager if the status changes and $s=B$.

(ii) If $K\left(R_{A}\right)<N \leq \frac{1}{1-\lambda} K\left(R_{A}\right)$ then the loyal manager chooses project $A$ with probability $\eta \in(0,1)$ and the status quo with probability $1-\eta$, and the disloyal manager chooses project B. Parameter $\eta$ satisfies $(\lambda \eta+1-\lambda) N=K\left(R_{A}\right)$. The shareholder fires the manager if the status quo changes and $s=B$. If in addition $\eta<\frac{1-\tau}{\tau}$, then shareholder fires the manager also when the status quo changes and $s=A$.

(iii) If $\frac{1}{1-\lambda} K\left(R_{A}\right)<N \leq \frac{1}{1-\lambda} K\left(b / \omega-R_{B}\right)$ then the loyal manager keeps the status quo and the disloyal manager chooses project $B$. Shareholder fires the manager if and only if the status quo changes. 
(iv) If $\frac{1}{1-\lambda} K\left(b / \omega-R_{B}\right)<N$ then then the loyal manager keeps the status quo and the disloyal manager chooses project $B$ with probability $\varphi \in(0,1)$ and the status quo with probability $1-\varphi$, such that $\varphi=\frac{1}{1-\lambda} \frac{K\left(b / \omega-R_{B}\right)}{N}$. Shareholder fires the manager if and only if the status quo changes.

Proof. The behavior of managers and the level of the price of resources are determined as in the Lemma 5 where $n$ is replaced by $N$ everywhere. For brevity we omit these arguments. Next, we characterize the decision of shareholders to fire the managers. Recall the shareholder fires the manager if and only if he believes that he is loyal with probability strictly smaller than $\lambda$. In part (i), unless the manager changes the status quo and a signal $s=A$ is obtained, the shareholder must infer that the manager is likely to be disloyal. Therefore, the shareholder fires the manager. In parts (iii-iv), a change to the status quo is an indication that the manager is disloyal regardless of the realization of signal $s$. Consider part (ii). The probability that the manager is loyal conditional on signal $s=A$ is $\frac{\lambda \eta \tau}{(1-\lambda)(1-\tau)+\lambda \eta \tau}$ and conditional on signal $s=B$ is $\frac{\lambda \eta(1-\tau)}{(1-\lambda) \tau+\lambda \eta(1-\tau)}$. Notice that $\frac{\lambda \eta \tau}{(1-\lambda)(1-\tau)+\lambda \eta \tau}<\lambda \Leftrightarrow \eta<\frac{1-\tau}{\tau}$ and $\frac{\lambda \eta(1-\tau)}{(1-\lambda) \tau+\lambda \eta(1-\tau)}<\lambda \Leftrightarrow \eta<\frac{\tau}{1-\tau}$. Noting that $\tau>\frac{1}{2}$ completes the proof.

Proposition 5 (Perfect shareholder competence) Suppose $\tau=1$ and $\Gamma>b-\omega R_{B}-$ $\omega R_{A}$. In equilibrium, all firms choose strong governance, but managers are never fired on the equilibrium path. The manager in each firm and irrespective of his loyalty, chooses project $A$ with probability $\min \left\{1, \frac{K\left(R_{A}\right)}{N}\right\}$ and the status quo otherwise. The price of resources is $p^{*}=$ $\min \left\{K^{-1}(N), R_{A}\right\}$. The expected shareholder value of a firm with strong governance is $v+$ $\min \left\{1, \frac{K\left(R_{A}\right)}{N}\right\}\left(R_{A}-p^{*}\right)+\lambda \Lambda$. The expected shareholder value of a firm with weak governance (off-equilibrium) is $v-p^{*}+\lambda R_{A}-(1-\lambda) R_{B}+\lambda \Lambda$.

Proof. Since the shareholder's competence has no direct effect on firms with weak governance, their behavior is characterized by Lemma 1. Consider firms with strong governance.

1. Suppose in equilibrium the price of resources is $p<R_{A}$. We argue that the manager chooses project A irrespective of his loyalty. To see why, suppose on the contrary the loyal manager chooses $\hat{x} \neq A$ in equilibrium. Since $p<R_{A}$, the loyal manager will not have a strict benefit from deviating to project A only if two conditions are met: (i) the loyal manager is not fired by choosing the equilibrium play $\hat{x}$, and (ii) he will be fired by choosing project A. Consider the following cases: 
(a) If $x=A$ is off-equilibrium (recall $\tau=1$ implies the shareholder observes the choice $x \in\{0, A, B\})$ then the beliefs that lead the shareholder to fire the manager upon $x=A$ violate the Grossman and Perry (1986) criterion. Indeed, $p<R_{A}$ and $\Gamma>b-\omega R_{B}-\omega R_{A}$ imply that both the loyal and disloyal manager will benefit from deviating to project A, knowing that the shareholder will not fire them upon such deviation. Since such deviation does not reveal information about the loyalty of the manager, the shareholder will have no incentives to fire him upon such deviation. Therefore, a contradiction. ${ }^{29}$

(b) If $x=A$ is on the equilibrium path, then it must also be chosen by the disloyal manager (or otherwise, the shareholder does not fire the manager upon $x=A$, as assumed). However, notice that if the disloyal manager is fired by the shareholder when choosing project A, then $b / \omega>R_{B}+R_{A}$ implies that the disloyal manager has a strictly profitable deviation to project $\mathrm{B}$, even if he expects to be fired upon doing so. Therefore, a contradiction.

We conclude that the loyal manager chooses project $\mathrm{A}$ with probability one in equilibrium. If so, it must be that the shareholder does not fire the manager upon observing $x=A$, even if the disloyal manager also chooses project $\mathrm{A}$ (since the replacement does not have a higher probability of being loyal). Moreover, if the disloyal manager chooses $x \neq A$, then he must be fired by the shareholder upon doing so. The assumptions $p<R_{A}$ and $\Gamma>b-\omega R_{B}-\omega R_{A}$ therefore guarantee that the disloyal manager has strict incentives to choose project A as well. We conclude that if $p<R_{A}$ then managers in firms with strong governance choose project A irrespective of their loyalty. Moreover, the shareholder does not fire the manager on the equilibrium path.

2. Suppose in equilibrium the price of resources is $p>R_{A}$. We argue that the manager chooses the status quo irrespective of his loyalty. To see why, suppose on the contrary the loyal manager chooses $\hat{x} \neq 0$ in equilibrium. Since $p>R_{A}$, the loyal manager will not have a strict benefit from deviating to the status quo only if two conditions are met: (i) the loyal manager is not fired by choosing the equilibrium play $\hat{x}$, and (ii) he will be fired by choosing the status quo. Consider the following cases:

\footnotetext{
${ }^{29}$ Notice that this argument does not hold when $\tau<1$. In this case, if the shareholder believes that both types choose project $\mathrm{A}$, the disloyal manager is better off choosing project B instead, knowing that the shareholder will interpret $s=B$ as an error and will not fire him. However, with $\tau=1$, the shareholder will not ascribe $s=B$ to an error, and will fire the manager in this case.
} 
(a) If $x=0$ is off-equilibrium then the beliefs that lead the shareholder to fire the manager upon $x=0$ violate the Grossman and Perry (1986) criterion. Indeed, $p>R_{A}$ implies that the loyal manager will benefit from deviating to $x=0$, knowing that the shareholder will not fire them upon such deviation. Since the shareholder will not fire the manager upon a deviation to $x=0$ even if he expects both types to choose $x=0$, we get a violation of the Grossman and Perry (1986) criterion, and therefore, a contradiction.

(b) If $x=0$ is on the equilibrium path, then it must also be chosen by the disloyal manager (or otherwise, the shareholder does not fire the manager upon $x=0$, as assumed). However, notice that if the disloyal manager is fired by the shareholder when choosing the status quo, then $b / \omega>R_{B}+R_{A}$ and the revealed preferences of the loyal manager imply that the disloyal manager has a strictly profitable deviation to the equilibrium choice of the loyal manager. Therefore, a contradiction.

We conclude that the loyal manager chooses the status quo with probability one in equilibrium. If so, it must be that the shareholder does not fire the manager upon observing $x=0$, even if the disloyal manager also chooses $x=0$. Moreover, if the disloyal manager chooses $x \neq 0$, then he must be fired by the shareholder upon doing so. The assumption $\Gamma>b-\omega R_{B}-\omega R_{A}$ and the revealed preferences of the loyal manager guarantee that the disloyal manager has strict incentives to choose $x=0$ as well. We conclude that if $p>R_{A}$ then managers in firms with strong governance choose the status quo irrespective of their loyalty. Moreover, the shareholder does not fire the manager on the equilibrium path.

3. Suppose in equilibrium the price of resources is $p=R_{A}$. In this case, project $\mathrm{A}$ and the status quo are identical from the perspective of the loyal and disloyal manager. Therefore, by applying the same arguments as in parts (1-2) above, any mixed strategy where both types choose project $\mathrm{A}$ with probability $\sigma$ and the status quo otherwise, can be supported as an equilibrium. For the same reasons as in parts (1-2) above, other strategies will not be an equilibrium.

According to parts (1-3) above, the expected shareholder value in firms with strong governance is $v+\max \left\{0, R_{A}-p\right\}$ and in firms with weak governance $v+\lambda \max \left\{0, R_{A}-p\right\}-$ $(1-\lambda)\left(R_{B}+p\right)$. Therefore, irrespective of the price of resources, shareholders are strictly better off choosing firms with strong governance. It remains to characterize the price of resources that clears the market. If $N \leq K\left(R_{A}\right)$ then note that even if all firms demand a change 
to the status quo the price will be weakly smaller than $R_{A}$. Therefore, in equilibrium, the market clearing price must also be smaller than $R_{A}$. This implies that the equilibrium play is as described by part (1) above, which implies that all firms invest in project A. Therefore, the equilibrium price of resources is $p^{*}=K^{-1}(N) \leq R_{A}$. Suppose $N>K\left(R_{A}\right)$. If on the contrary the equilibrium price is strictly larger than $R_{A}$, then according to part (2) above, no firm changes the status quo, which implies that the equilibrium price is $K^{-1}(0)=\underline{p}<R_{A}$, a contradiction. If instead the equilibrium price is strictly smaller than $R_{A}$, then according to part (1) above, all firms change the status quo, which implies that the equilibrium price is $K^{-1}(N)>R_{A}$, a contradiction. Therefore, if an equilibrium exists, the price must be $R_{A}$. If the equilibrium price is $R_{A}$, it can clear the market only if the number of firms which demand a change to the status quo is $K\left(R_{A}\right)$. Based on part (3) above, the manager chooses project A with probability $\sigma$ and the status quo otherwise. Therefore, the mixing probability $\sigma$ is set such that $\sigma N=K\left(R_{A}\right)$, as required. 